AperTO - Archivio Istituzionale Open Access dell'Università di Torino

4-Hydroxy-1,2,5-oxadiazol-3-yl Moiety as Bioisoster of the Carboxy Function. Synthesis, Ionization Constants, and Molecular Pharmacological Characterization at lonotropic Glutamate Receptors of Compounds Related to Glutamate and Its Homologues

This is the author's manuscript

Original Citation:

Availability:

This version is available http://hdl.handle.net/2318/76221

since

Published version:

DOI:10.1021/jm1001452

Terms of use:

Open Access

Anyone can freely access the full text of works made available as "Open Access". Works made available under a Creative Commons license can be used according to the terms and conditions of said license. Use of all other works requires consent of the right holder (author or publisher) if not exempted from copyright protection by the applicable law. 


\title{
4-Hydroxy-1,2,5-oxadiazol-3-yl Moiety as Bioisoster of the Carboxy Function. Synthesis, Ionization Constants, and Molecular Pharmacological Characterization at Ionotropic Glutamate Receptors of Compounds Related to Glutamate and Its Homologues
}

\author{
Marco L. Lolli, ${ }^{\dagger}$ Cecilia Giordano, ${ }^{\dagger}$ Darryl S. Pickering, ${ }^{\dagger}$ Barbara Rolando, ${ }^{\dagger}$ Kasper B. Hansen,,${ }^{\S}$, Antonio Foti, ${ }^{\dagger}$ \\ Alberto Contreras-Sanz, ${ }^{*}$ Ahmad Amir, ${ }^{\star}$ Roberta Fruttero, ${ }^{\dagger}$ Alberto Gasco, ${ }^{* \dagger}{ }^{\dagger}$ Birgitte Nielsen, ${ }^{\S}$ and Tommy N. Johansen*, ${ }^{*}$ \\ ${ }^{\dagger}$ Dipartimento di Scienza e Tecnologia del Farmaco, Università degli Studi di Torino, Via Pietro Giuria 9, 10125 Torino, Italy, ${ }^{\star}$ Department of \\ Pharmacology and Pharmacotherapy, and ${ }^{\S}$ Department of Medicinal Chemistry, Faculty of Pharmaceutical Sciences, University of Copenhagen, \\ 2 Universitetsparken, DK-2100 Copenhagen, Denmark, and" Department of Molecular Biology, H. Lundbeck A/S, Copenhagen, Denmark
}

Received February 3, 2010

\begin{abstract}
In order to investigate the 4-hydroxy-1,2,5-oxadiazol-3-yl moiety as a carboxylic acid bioisoster at ionotropic glutamate receptors (iGluRs), a series of acidic $\alpha$-aminocarboxylic acids in which the distal carboxy group was replaced by the 4-hydroxy-1,2,5-oxadiazol-3-yl group was synthesized. Ionization constants were determined. All target compounds, except the Asp analogue 12, were resolved using chiral HPLC. Whereas 12 showed good affinity exclusively at NMDA receptors, the Glu analogue, $(+)-$ 10, was an unselective, though potent AMPA receptor preferring agonist $\left(\mathrm{EC}_{50}=10 \mu \mathrm{M}\right.$ at iGluR2) showing only low stereoselectivity. The two higher Glu homologues, $(+)-\mathbf{1 5}$ and $(+)-\mathbf{1 8}$, turned out to be weak agonists at iGluR2 as well as weak antagonists at NR1/NR2A, whereas the corresponding (-)isomers were selective NR1/NR2A antagonists with somewhat higher potency. The results proved the 4-hydroxy-1,2,5-oxadiazol-3-yl moiety to be a useful bioisoster at all three classes of iGluRs, capable of being integrated into agonists as well as antagonists.
\end{abstract}

\section{Introduction}

$(S)$-Glutamate $\left((S)\right.$-Glu, ${ }^{a}$ Figure 1) plays a major role in the transmission of excitatory signals in the central nervous system (CNS) and is implicated in epilepsy, pain, memory, excitotoxicity, and brain development. ${ }^{1}$ It mediates its actions through two classes of receptors (GluRs). The first class consists of ionotropic glutamate receptors (iGluRs) that are classified according to their selective agonists into NMDA ( $N$-methyl-D-aspartate), AMPA ( $R S)$-2-amino-3-(3-hydroxy5-methylisoxazol-4-yl)propionic acid, 1, Figure 1) and KA (kainic acid) receptors. The second class consists of metabotropic glutamate receptors (mGluRs) that are divided into three groups (I, II, III) each containing at least two subtypes. The vast majority of both iGluR and mGluR subtypes are considered interesting therapeutic targets for the treatment of a number of neurologic and psychiatric diseases. 1,2

Specific agonists and antagonists are necessary in order to characterize the physiological roles of the individual receptors.

\footnotetext{
*To whom correspondence should be addressed. For A.G.: phone, +390116707670; fax, +390116707687; e-mail, alberto.gasco@unito.it. For T.N.J.: phone, +45 35336412; fax, +45 35336040; e-mail, tnj@ farma.ku.dk.

${ }^{a}$ Abbreviations: $(S)$-Glu, $(S)$-glutamate; CNS, central nervous system; iGluRs, ionotropic glutamate receptors; NMDA, $N$-methyl-Daspartate; AMPA, $(R S)$-2-amino-3-(3-hydroxy-5-methylisoxazol-4-yl)propionic acid; KA, kainic acid; mGluRs, metabotropic glutamate receptors; TDPA, ( $R S$ )-2-amino-3-(4-hydroxy-1,2,5-thiadiazol-3-yl)propionic acid; GABA, $\gamma$-aminobutyric acid; $\left[{ }^{3} \mathrm{H}\right] \mathrm{CGP} 39653$, $\left[{ }^{3} \mathrm{H}\right](R S)-(E)$-2-amino-4-phosphonomethyl-3-heptenoic acid; THF, tetrahydrofurane; NBS, $N$-bromosuccinimide; $\mathrm{Tf}_{2} \mathrm{O}$, triflic anhydride; TLC, thin layer chromatography; CD, circular dichroism.
}

In the design of selective receptor ligands, isosteric replacement of moieties in a lead structure is one of the most frequently used approaches. $^{3-7}$ This approach should be carried out taking into account that a particular isosteric group proven to be a bioisoster in one lead compound may not necessarily be successful in another. In the designing of mimetics of endogenous acidic amino acids, a number of bioisosteric replacements of the carboxylic group have been described ${ }^{8}$ and especially $3-$ hydroxyisoxazol-4-yl has been a well studied example at iGluRs. ${ }^{9}$ Quite recently, another hydroxy-substituted heterocycle, 4-hydroxy-1,2,5-thiadiazol-3-yl, was substituted for the distal carboxylic group in Glu to give 2-amino-3-(4-hydroxy1,2,5-thiadiazol-3-yl)propionic acid (TDPA, 2, Figure 1) which shows a preference for the AMPA subtype of iGluRs. ${ }^{10} \mathrm{Re}-$ cently, we proposed the 4-hydroxy-1,2,5-oxadiazol-3-yl moiety as a potential bioisoster of the $\mathrm{COOH}$ function and we explored the possibility of obtaining biomimetics of $\gamma$-aminobutyric acid (GABA), the major inhibitory neurotransmitter in the CNS. This approach gave rise to compounds with partial agonist profiles at $\mathrm{GABA}_{\mathrm{A}}$ receptors. ${ }^{11}$ In this paper we describe the synthesis, ionization properties, resolution, and molecular pharmacological characterization at native and recombinant

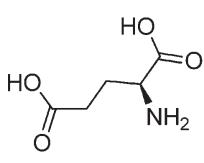

(S)-Glu

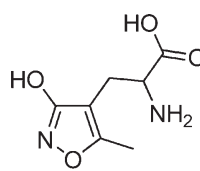

AMPA (1)

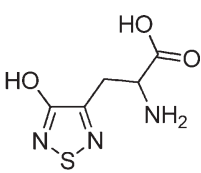

TDPA (2)
Figure 1. Structures of (S)-Glu and selected heterocyclic analogues. 
Scheme 1. Synthesis of Target Compounds 10, 12, 15, and 18

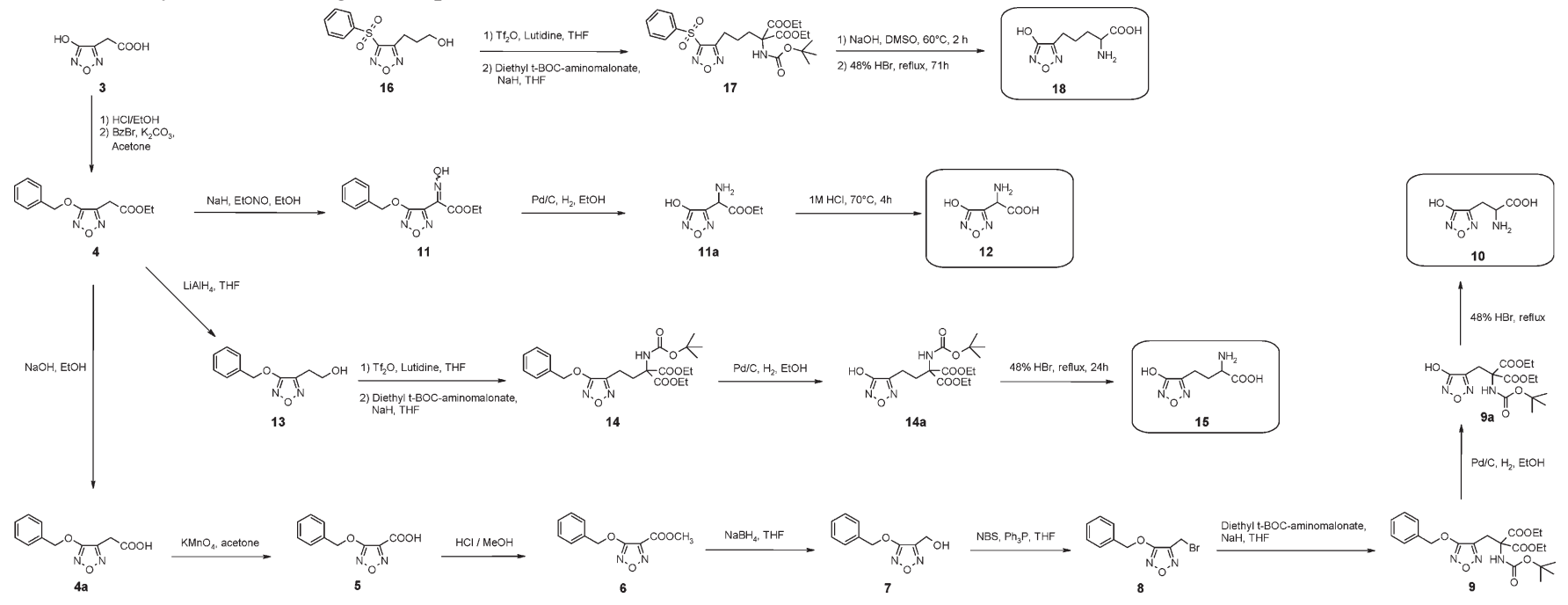

iGluRs of the target compounds 10, 12, 15, and 18. These compounds can be formally derived from Glu, its inferior homologue, and its two superior homologues by substitution of the distal $\mathrm{COOH}$ group with the 4-hydroxy-1,2,5-oxadiazol3-yl moiety.

\section{Results and Discussion}

Chemistry. The synthetic pathways used to prepare the target compounds 10, 12, 15, 18 are reported in Scheme 1. The strict analogue $\mathbf{1 0}$ of Glu was prepared starting from (4hydroxy-1,2,5-oxadiazol-3-yl)acetic acid (3) that was transformed into the corresponding ethyl ester by action of gaseous $\mathrm{HCl}$ in dry ethanol. The ester was purified by flash chromatography and immediately treated with benzyl bromide in acetone in the presence of $\mathrm{K}_{2} \mathrm{CO}_{3}$ to afford the ester 4. Basic hydrolysis of $\mathbf{4}$ afforded $\mathbf{4 a}$ that by $\mathrm{KMnO}_{4}$ lateral chain oxidative demolition produced the benzyloxyl substituted 1,2,5-oxadiazolecarboxylic acid 5. Methyl ester $\mathbf{6}$ was obtained from $\mathbf{5}$ in dry methanol solution saturated with gaseous $\mathrm{HCl}$. Reduction of the ester function of $\mathbf{6}$ carried out with $\mathrm{NaBH}_{4}$ in tetrahydrofuran (THF) yielded the alcohol 7. The related bromo derivative $\mathbf{8}$ was obtained by treating 7 with $N$-bromosuccinimide (NBS) in THF in the presence of $\mathrm{Ph}_{3} \mathrm{P}$. A THF solution of this last intermediate was allowed to react with diethyl [(tert-butoxycarbonyl)amino]malonate and $\mathrm{NaH}$ mineral oil dispersion to give $9 . \mathrm{Pd} / \mathrm{C}, \mathrm{H}_{2}$ reduction of 9 afforded 9a that was refluxed in $\mathrm{HBr}$ water solution to afford, after ion exchange chromatography, the racemic mixture 10. Synthesis of the racemic mixture of $\mathbf{1 2}$ was carried out by nitrosation of the active methylene of $\mathbf{4}$ and subsequent reduction of oxime $\mathbf{1 1}$ with $\mathrm{Pd} / \mathrm{C}, \mathrm{H}_{2}$ followed by immediate $\mathrm{HCl}$ hydrolysis of the intermediate ester 11a. To prepare the racemic mixture 15, the intermediate 4 was transformed into the alcohol $\mathbf{1 3}$ by action of $\mathrm{LiAlH}_{4}$ in THF. Alcohol 13, treated with triflic anhydride $\left(\mathrm{Tf}_{2} \mathrm{O}\right)$ in the presence of 2,6-lutidine afforded the corresponding trifluoromethanesulfonate, which was quickly purified by flash chromatography and immediately allowed to react with diethyl [(tert-butoxycarbonyl)amino]malonate and $\mathrm{NaH}$ mineral oil dispersion to give 14. This last product, treated under the same conditions used to prepare $\mathbf{1 0}$ from $\mathbf{9}$, gave rise to the final compound $\mathbf{1 5}$ through the intermediate formation of $\mathbf{1 4 a}$. Synthesis of $\mathbf{1 7}$ was carried out by treating
Table 1. $\mathrm{p} K_{\mathrm{a}}$ Values $( \pm \mathrm{SD})$ of Compounds 10, 12, 15, 18 as Determined by Potentiometry ${ }^{a}$

\begin{tabular}{lccl}
\hline & \multicolumn{3}{c}{$\mathrm{p} K_{\mathrm{a}} \pm \mathrm{SD}$} \\
\cline { 2 - 4 } compd & $\mathrm{p} K_{\mathrm{a} 1}(\alpha-\mathrm{COOH})$ & $\mathrm{p} K_{\mathrm{a} 2}$ & $\mathrm{p} K_{\mathrm{a} 3}\left(\mathrm{NH}_{3}{ }^{+}\right)$ \\
\hline Glu & 2.2 & 4.2 & 9.6 \\
Asp & 2.0 & 3.9 & 10.0 \\
Gly & 2.3 & & 9.8 \\
$\mathbf{1 2}$ & $1.88 \pm 0.27$ & $3.37 \pm 0.03$ & $7.60 \pm 0.01$ \\
$\mathbf{1 0}$ & $1.90 \pm 0.19$ & $3.48 \pm 0.02$ & $8.81 \pm 0.01$ \\
$\mathbf{1 5}$ & $2.12 \pm 0.05$ & $3.68 \pm 0.03$ & $9.10 \pm 0.02$ \\
$\mathbf{1 8}$ & $2.48 \pm 0.04$ & $3.69 \pm 0.02$ & $9.39 \pm 0.01$ \\
\hline
\end{tabular}

${ }^{a}$ Glu, Asp, and Gly $\mathrm{p} K_{\mathrm{a}}$ values are shown for comparison.

alcohol $\mathbf{1 6}$ in the same conditions used to prepare $\mathbf{1 4}$ from $\mathbf{1 3}$. Treatment of $\mathbf{1 7}$ with $\mathrm{NaOH}$ in DMSO induced nucleophilic substitution of the phenylsulfonyl group with consequent formation of the corresponding sulfinic acid and partial hydrolysis of ethyl ester moieties. Treatment of this mixture with Oxone at controlled $\mathrm{pH}$, in order to oxidate phenylsulfinic acid to the more acidic sulfonic acid, and subsequent extraction with diethyl ether of the resulting mixture gave a crude material that was refluxed in aqueous $\mathrm{HBr}$ to yield target compound $\mathbf{1 8}$.

Ionization Constants. The ionization constants $\left(\mathrm{p} K_{\mathrm{a}}\right.$ values) for the final compounds $\mathbf{1 0}, \mathbf{1 2}, \mathbf{1 5}, \mathbf{1 8}$ were obtained by potentiometric titration using a GLpKa apparatus. The $\mathrm{p} K_{\mathrm{a}}$ values are collected in Table 1 . The products show three dissociation constants in the ranges $\mathrm{p} K_{\mathrm{a} 1}=1.88-2.48, \mathrm{p} K_{\mathrm{a} 2}=$ $3.37-3.69$, and $\mathrm{p} K_{\mathrm{a} 3}=7.60-9.39$. The first two ranges are related to the dissociation of the two acid functions, while the third is related to $\mathrm{p} K_{\mathrm{a}}$ values of the basic $-\mathrm{NH}_{2}$ function. A comparison of these data with the $\mathrm{p} K_{\mathrm{a}}$ values of Glu, Asp, and $\mathrm{Gly}^{12}$ (Table 1) indicates that it is reasonable to assign the first and the second sets to the prevalent dissociation of the $\mathrm{COOH}$ function and of the hydroxyl-1,2,5-oxadiazole moiety, respectively. The third set is then assigned to the $\mathrm{NH}_{3}{ }^{+}$group. At physiological $\mathrm{pH}$, products $\mathbf{1 5}$ and $\mathbf{1 8}$ exist, similar to Glu and ASP, predominantly in the anionic tricharged form $(--+)$, while in 12, and partly in 10, this species is in equilibrium with the dianionic form $(--)$.

At AMPA receptors, groups known to behave as bioisosters of the distal $\mathrm{COOH}$ function cover a $\mathrm{p} K_{\mathrm{a}}$ range where the ionized form predominates in aqueous solutions. ${ }^{13,14} \mathrm{~A}$ low 
degree of ionization is expected to disfavor binding by shifting the equilibrium away from the presumably active form carrying three charges. The high degree of acidity exhibited by the hydroxyfurazan moiety should be favorable in this sense.

Chiral HPLC Resolution of Stereomers. The resolution of compounds 10, 12, 15, and 18 was performed on a Crownpak $\mathrm{CR}(+)$ semipreparative column, using $15 \mathrm{mM}$ aqueous acetic acid ( $\mathrm{pH}$ 3.0) as the mobile phase. The stereochemical purity of each obtained enantiomer was $>99 \%$. For all the products the first eluted enantiomers were the levorotatory (-) ones. It is interesting to point out that the specific rotations $[\alpha]^{25}$ found for $\mathbf{1 0}$ and $\mathbf{1 5}$ are close to those of the corresponding thio analogues. ${ }^{10,15} \mathrm{On}$ the basis of the observed elution order of corresponding thio analogues on the Crownpak column ${ }^{10,15}$ as well as the general elution order of a series of racemic $\alpha$-amino acids, the first-eluting (-)-isomers of compounds $\mathbf{1 0}, \mathbf{1 5}$, and $\mathbf{1 8}$ are believed to possess $R$-configuration. ${ }^{16}$ No acceptable resolution was achieved for compound $\mathbf{1 2}$ or its $N$-Boc protected derivative, although a number of chiral stationary phases and eluents were investigated. NMR experiments, performed in $\mathrm{D}_{2} \mathrm{O}$ studying the rate of deuterium exchange of the $\alpha-\mathrm{H}$ in compound 12, showed that the $\alpha-\mathrm{H}$ undergoes quick exchange, most likely too fast for a successful resolution of $\mathbf{1 2}$.

Radioligand Binding at iGluRs. The affinities of the racemates and the isolated enantiomers for native AMPA, KA,

Table 2. Receptor Binding Affinities at Native Rat iGluRs ${ }^{a}$

\begin{tabular}{llll}
\hline & \multicolumn{2}{c}{$\mathrm{IC}_{50}(\mu \mathrm{M})$} & \multicolumn{1}{c}{$K_{\mathrm{i}}(\mu \mathrm{M})$} \\
\cline { 2 - 3 } \multicolumn{1}{c}{ compd } & AMPA receptors & \multicolumn{1}{c}{ KA receptors } & \multicolumn{1}{c}{ NMDA receptors } \\
\hline$(S)-\mathrm{Glu}^{b}$ & 0.34 & 0.38 & 0.20 \\
${\text { AMPA }(\mathbf{1})^{c}}^{c}$ & 0.039 & $>100$ & $>100$ \\
$\mathrm{KA}$ & $4.0^{d}$ & $0.007^{d}$ & $>100$ \\
NMDA $^{b}$ & $>100$ & $>100$ & 6.2 \\
$\left.\mathrm{TDPA}^{(2}\right)^{e}$ & 0.12 & $>100$ & $>100^{f}$ \\
$\mathbf{1 2}$ & $>100$ & $>100$ & $6.3[5.20 \pm 0.02]$ \\
$\mathbf{1 0}$ & $0.17[6.76 \pm 0.05]$ & $49[4.31 \pm 0.05]$ & $16[4.80 \pm 0.03]$ \\
$(+)-\mathbf{1 0}$ & $0.11[6.95 \pm 0.03]$ & $18[4.76 \pm 0.03]$ & $13[4.90 \pm 0.03]$ \\
$(-)-\mathbf{1 0}$ & $0.76[6.12 \pm 0.06]$ & $>100$ & $>100$ \\
$\mathbf{1 5}$ & $77[4.12 \pm 0.07]$ & $>100$ & $4.9[5.31 \pm 0.03]$ \\
$(+)-\mathbf{1 5}$ & $42[4.37 \pm 0.03]$ & $>100$ & $73[4.13 \pm 0.02]$ \\
$(-)-\mathbf{1 5}$ & $>100$ & $>100$ & $3.4[5.47 \pm 0.05]$ \\
$\mathbf{1 8}$ & $61[4.22 \pm 0.07]$ & $>100$ & $2.9[5.54 \pm 0.06]$ \\
$(+)-\mathbf{1 8}$ & $42[4.37 \pm 0.01]$ & $>100$ & $22[4.66 \pm 0.05]$ \\
$(-)-\mathbf{1 8}$ & $>100$ & $>100$ & $1.8[5.75 \pm 0.06]$ \\
\hline
\end{tabular}

${ }^{a}$ AMPA, KA, and NMDA receptors were studied using $\left[{ }^{3} \mathrm{H}\right] \mathrm{AMPA}$, $\left[{ }^{3} \mathrm{H}\right] \mathrm{KA}$, and $\left[{ }^{3} \mathrm{H}\right] \mathrm{CGP} 39653$ as radioligands, respectively. Mean $\mathrm{pIC}_{50}$ $\pm \mathrm{SEM}$ and $\mathrm{p} K_{\mathrm{i}} \pm \mathrm{SEM}$ (shown in brackets) and the corresponding $\mathrm{IC}_{50}$ and $K_{\mathrm{i}}$ values were calculated from full concentration-response curves of three individual experiments. ${ }^{b}$ Reference $17 .{ }^{c}$ Reference $18 .{ }^{d}$ Reference $19 .{ }^{e}$ Reference $10 .{ }^{f}\left[{ }^{3} \mathrm{H}\right] \mathrm{CPP}$ binding. and NMDA receptor sites were determined in receptor binding assays at rat brain membrane preparations using the radioligands $\left[{ }^{3} \mathrm{H}\right] \mathrm{AMPA},\left[{ }^{3} \mathrm{H}\right] \mathrm{KA}$, and $\left[{ }^{3} \mathrm{H}\right](R S)-(E)-2-$ amino-4-phosphonomethyl-3-heptenoic acid ([ $\left.{ }^{3} \mathrm{H}\right] \mathrm{CGP}$ 39653). The results are reported in Table 2.

Compound 12 showed affinity and preference for NMDA receptors similar to that of NMDA itself and the corresponding 5-methyl-3-hydroxyisoxazole analogue, ${ }^{20}$ whereas compounds 15 and 18 displayed affinities for both NMDA and AMPA, but not for KA, receptor sites. For compounds $\mathbf{1 5}$ and 18, the AMPA receptor affinity resided in the $(+)$ isomers, whereas all four $\mathbf{1 5}$ and $\mathbf{1 8}$ isomers showed affinity for NMDA receptor sites with the (-)-enantiomers being eutomers. For 15, the observed profile at ionotropic receptor sites was different from the corresponding hydroxythiadiazole analogue, which does not show measurable affinity for native iGluR sites. ${ }^{15}$ Compound 10, the close analogue of Glu, not only displayed quite potent affinity for AMPA receptors similar to that of AMPA (1) and $\operatorname{TDPA}^{10}$ (2) but also turned out to be an unselective iGluR ligand, although with some preference for AMPA receptors. The pharmacology profile of $\mathbf{1 0}$ is quite different from those of the corresponding 3-hydroxyisoxazole ${ }^{21}$ and the corresponding hydroxythiadiazole ${ }^{10}(\mathbf{2})$ analogues which interact selectively with the AMPA receptor subtype of iGluRs. At all three classes of native iGluRs the affinity of $\mathbf{1 0}$ was shown to reside mainly in the $(+)$-isomer. Similar to TDPA,${ }^{10}$ the interaction of 10 with AMPA receptors showed low stereoselectivity, as $(+)-\mathbf{1 0}$ is only approximately 6 times more potent than the other enantiomer. Since the stereochemical purity of $(-)-\mathbf{1 0}$ is very high $(99.6 \%$ ee), the observed affinity at AMPA receptors is not caused by a stereochemical impurity. The lower affinity for NMDA and KA receptors prevents any quantitative comparison of stereoselectivity at these sites.

Furthermore, $(+)$ - and $(-)-\mathbf{1 0}$ were evaluated in receptor binding at the cloned AMPA receptor $\mathrm{iGluR} 2(R)_{\mathrm{O}}$ and KA

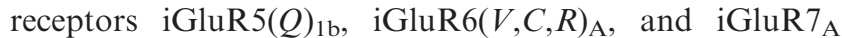
(Table 3). At both iGluR2 and iGluR5 receptors $(+)-10$ was the most potent isomer, being 6 - and 10 -fold more potent compared to $(-)-\mathbf{1 0}$, respectively. $(+)-\mathbf{1 0}$ was demonstrated to be almost as potent as AMPA ${ }^{22}$ at iGluR2 and iGluR 5 but did not show any affinity for iGluR6 or iGluR7. Whereas $(+)-\mathbf{1 0}$ was more than 100-fold more potent at iGluR2 than at iGluR 5 receptors, neither $(+)-\mathbf{1 5}$ nor $(+)-\mathbf{1 8}$ showed any preference for $\mathrm{iGluR} 2$ receptors.

Functional Studies at Representative Recombinant iGluRs. Active enantiomers were characterized functionally at selected AMPA and NMDA receptor subtypes (Table 4). The concentration-response data of the stereoisomers and the calculated $\mathrm{EC}_{50}$ values generally supported the affinity data reported in Table 3. At iGluR2, $(+)$ - and $(-)-\mathbf{1 0}$ as well as $(+)-\mathbf{1 5}$ and $(+)-\mathbf{1 8}$ turned out to be agonists (Figure 2 ) with

Table 3. Receptor Binding Affinities at Cloned Rat Subtypes Expressed in Sf9 Cells ${ }^{a}$

\begin{tabular}{|c|c|c|c|c|}
\hline \multirow[b]{2}{*}{ compd } & \multicolumn{4}{|c|}{$K_{\mathrm{i}}(\mu \mathrm{M})$} \\
\hline & $\mathrm{iGluR} 2(R)_{\mathrm{o}}$ & $\operatorname{iGluR} 5(Q)_{1 \mathrm{~b}}$ & iGluR6 $(V, C, R)_{\mathrm{A}}$ & iGluR7 \\
\hline$(S)$-Glu & $0.28[6.55 \pm 0.08]$ & $0.14[6.86 \pm 0.01]$ & $0.33[6.48 \pm 0.02]$ & $0.49[6.31 \pm 0.03]$ \\
\hline$(+)-10$ & $0.043[7.37 \pm 0.02]$ & $8.1[5.09 \pm 0.01]$ & $>100$ & $>100$ \\
\hline$(-)-10$ & $0.25[6.60 \pm 0.03]$ & $77[4.11 \pm 0.01]$ & $>100$ & $>100$ \\
\hline$(+)-15$ & $40[4.39 \pm 0.07]$ & $53[4.27 \pm 0.02]$ & $>1000$ & $41[4.38 \pm 0.07]$ \\
\hline$(+)-18$ & $20[4.69 \pm 0.02]$ & $67[4.18 \pm 0.06]$ & $>1000$ & $>1000$ \\
\hline
\end{tabular}

\footnotetext{
${ }^{a}$ Mean $\mathrm{p} K_{\mathrm{i}} \pm \mathrm{SEM}$ (shown in brackets) and the corresponding $K_{\mathrm{i}}$ values were calculated from full concentration-response curves of three individual
} experiments. 
Table 4. Functional Characterization at Selected Cloned AMPA and NMDA Receptors

\begin{tabular}{|c|c|c|c|c|c|}
\hline \multirow[b]{2}{*}{ compd } & \multicolumn{2}{|c|}{ iGluR2 $(Q)_{\mathrm{i}}$ expressed in Xenopus oocytes ${ }^{a, c}$} & \multicolumn{3}{|c|}{ NR1-1a/NR2A expressed in BHK-21 cells ${ }^{b, c}$} \\
\hline & $\mathrm{EC}_{50}(\mu \mathrm{M})$ & relative $I_{\max }$ & $\mathrm{EC}_{50}(\mu \mathrm{M})$ & relative $F_{\max }$ & $\mathrm{IC}_{50}(\mu \mathrm{M})$ \\
\hline (S)-Glu & $14[4.86 \pm 0.04]$ & 1.00 & $1.8[5.75 \pm 0.12]$ & 1.00 & \\
\hline$(+)-10$ & $9.4[5.03 \pm 0.05]$ & $0.92 \pm 0.03$ & $47[4.33 \pm 0.13]$ & $0.76 \pm 0.02$ & \\
\hline$(-)-10$ & $43[4.37 \pm 0.04]$ & nd & $>500$ & nd & \\
\hline$(+)-15$ & $489[3.31 \pm 0.09]$ & nd & $\mathrm{nr}$ & & $1024[2.99 \pm 0.01]$ \\
\hline$(-)-15$ & nd & nd & $\mathrm{nr}$ & & $49[4.31 \pm 0.04]$ \\
\hline$(+)-18$ & $491[3.31 \pm 0.06]$ & nd & $\mathrm{nr}$ & & $245[3.61 \pm 0.04]$ \\
\hline$(-)-18$ & nd & nd & $\mathrm{nr}$ & & $28[4.55 \pm 0.06]$ \\
\hline
\end{tabular}

${ }^{a}$ Parameters measured by TEVC recordings. Mean $\mathrm{pEC}_{50} \pm \mathrm{SEM}$ (shown in brackets) and the corresponding $\mathrm{EC}_{50}$ values were calculated from full concentration-response curves. The mean relative maximal response $\left(I / I_{\max } \pm \mathrm{SEM}\right)$ is relative to maximal steady-state currents evoked by $(S)$-Glu. The number of oocytes was between 5 and $13 .{ }^{b}$ Parameters measured by $\left[\mathrm{Ca}^{2+}\right]_{\mathrm{i}}$ measurements. Mean $\mathrm{pEC} 50 \pm \mathrm{SEM}$ (shown in brackets) and the corresponding $\mathrm{EC}_{50}$ values as well as relative $F_{\max } \pm \mathrm{SEM}$ (relative to $F_{\max }$ of $(S)$-Glu) (maximal response to glutamate, 1.0 ) were calculated from full concentration-response curves. For the agonist data the Hill coefficients were between 1.1 and 1.5, and the number of experiments was 3 . Inhibition of NMDA receptor subtype, NR1-1a/NR2A, by increasing concentrations of antagonists was performed using $6 \mu \mathrm{M}(S)$-Glu. The mean pIC $50 \pm$ SEM (shown in brackets) and the corresponding $\mathrm{IC}_{50}$ values were calculated from full concentration-response curves. For all antagonist data, the number of experiments was $3 .^{c}$ nd: not determined. nr: no response to $1000 \mu \mathrm{M}$.

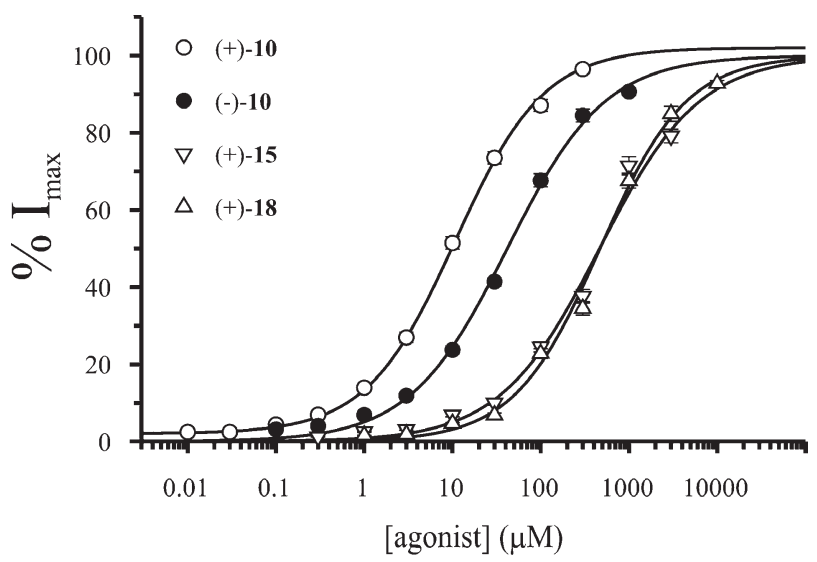

Figure 2. Electrophysiological activity at iGluR2 expressed in Xenopus oocytes.

relative potencies to some extent in agreement with the affinities reported in Table 3. Efficacy measurements conducted for $(+)-\mathbf{1 0}$ at $\mathrm{iGluR} 2(Q)_{\mathrm{i}}$ indicated that the compound has an efficacy that was statistically significantly lower (paired $t$ test, $P=0.037$ ), $0.92 \pm 0.03$ (mean \pm SEM, $n=8$ ) relative to $(S)$-Glu (efficacy $=1.000)$.

Furthermore, enantiomers displaying affinity at native NMDA receptor sites were studied at NR1/NR2A receptors expressed in BHK-21 cells using intracellular calcium measurements. $^{23}(+)-\mathbf{1 0}$ displayed a partial agonist profile (Figure $3 \mathrm{a}$ and Table 4). The enantiomers of $\mathbf{1 5}$ and $\mathbf{1 8}$ were inactive when tested for agonistic activity. However, (-)-15 and ( - -18 behaved as antagonists with similar potencies (Figure 3b). Also, the related (+)-enantiomers showed antagonistic activity but their IC $_{50}$ values (Table 4) were markedly higher complementing the affinity data of Table 3. It is interesting that the stereoselectivity of compound $\mathbf{1 5}$, with (-)-15 being the more potent isomer, is also seen with the corresponding hydroxythiadiazole analogue of $\mathbf{1 5},{ }^{15}$ although this compound is markedly less potent than (-)15 at NMDA receptors.

\section{Conclusions}

The results reported in the present work show that the 4-hydroxy-1,2,5-oxadiazol-3-yl moiety, when incorporated in Asp and Glu-related compounds as well as the two higher homologues, gives rise to products that are uniquely recog-
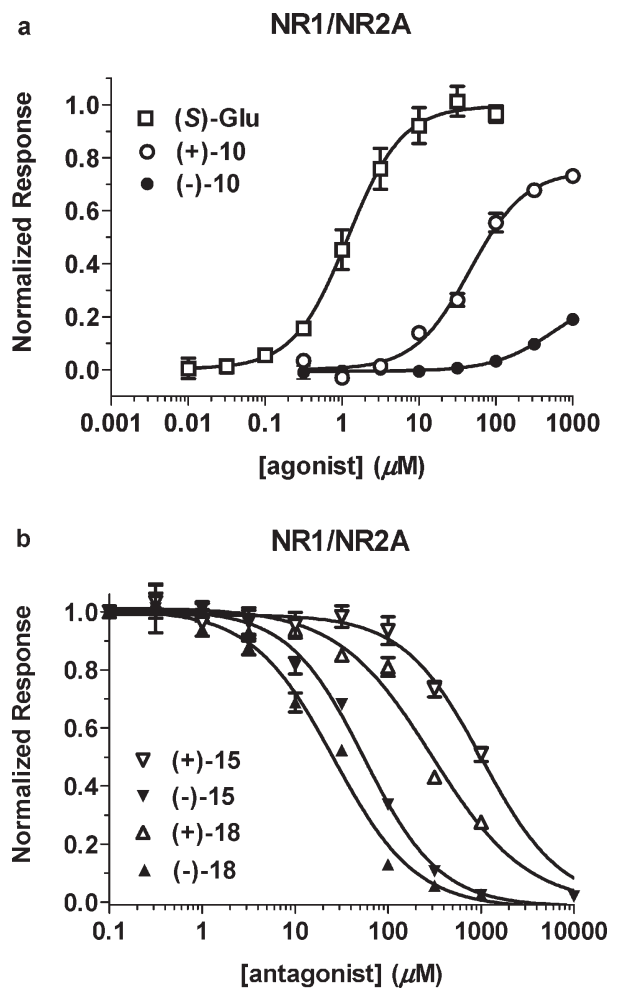

Figure 3. Activity at NR1/NR2A receptors expressed in BHK-21 cells. (a) Representative concentration-response data determined by intracellular calcium measurements at NR1-1a/NR2A receptors expressed in BHK-21 cells. The maximal fluorescence response to $(S)$-Glu $\left(F_{\max ,(S) \text {-Glu }}\right)$ is normalized to 1 , and the minimal response $\left(F_{\text {min }}\right)$ is normalized to 0 . The fluorescence responses to the agonists are normalized to $F_{\max ,(S) \text {-Glu }}$. Data points are represented as the mean $\pm \mathrm{SD}$ of four to six wells. (b) Representative concentration-response curves for inhibition of $(S)$-Glu-induced responses determined by intracellular calcium measurements at NR1-1a/ NR2A receptors expressed in BHK-21 cells. The responses were induced by coapplication of $6 \mu \mathrm{M}(S)$-Glu. Data points are represented as the mean $\pm \mathrm{SD}$ of four to six wells..

nized by iGluRs. Among the four new acidic amino acids, the strict Glu analogue $\mathbf{1 0}$ turned out to have a pharmacological profile very similar to that of Glu, being an unselective but AMPA-receptor preferring agonist, with $\mathrm{EC}_{50}=10 \mu \mathrm{M}$ at iGluR2 and a relative efficacy of 0.92. At iGluR2, iGluR5, and NR1/NR2A, (+)-10 was shown to be the eutomer. These results indicate that biomimetics of Asp, Glu, and their 
homologues can be obtained by substitution of the distal carboxylic acid with the isoster 4-hydroxy-1,2,5-oxadiazol-3yl substructure.

\section{Experimental Section}

Chemistry. Melting points were determined on a Büchi 530 apparatus or an SRS Optimelt apparatus and are uncorrected. The compounds were routinely checked by mass spectrometry (Finnigan-MatTSQ-700 spectrometer, $70 \mathrm{eV}$, direct inlet). ${ }^{1} \mathrm{H}$ NMR spectra and proton decoupled ${ }^{13} \mathrm{C}$ NMR spectra were recorded on a Bruker AC-300 spectrometer. The following abbreviations are used to indicate peak multiplicity: $\mathrm{s}=$ singlet; $\mathrm{d}=$ doublet; $\mathrm{dd}=$ doublet of doublet; $\mathrm{t}=$ triplet; $\mathrm{q}=$ quartet; $\mathrm{m}=$ multiplet. Flash column chromatography was performed on silica gel (Merck Kieselgel 60, 230-400 mesh ASTM) using the indicated eluents. Thin layer chromatography (TLC) was carried out on $5 \mathrm{~cm} \times 20 \mathrm{~cm}$ plates with a layer thickness of $0.25 \mathrm{~mm}$. When necessary, they were developed using UV light, iodine, $\mathrm{KMnO}_{4}$, and ninhydrin. Anhydrous magnesium sulfate was used as drying agent of the organic extracts. Elemental analyses of new compounds were within $\pm 0.4 \%$ of the theoretical values unless otherwise stated. The moisture sensitive reactions were performed under dry $\mathrm{N}_{2}$ or Ar. Tetrahydrofuran (THF) was distilled immediately before use from sodium and benzophenone under nitrogen. Compounds $3^{24}$ and $\mathbf{1 6}^{11}$ and diethyl [(tert-butoxycarbonyl)amino]malonate ${ }^{25}$ were synthesized according to the literature methods. The chemicals $\mathrm{NaH}$ $(60 \% \mathrm{w} / \mathrm{w})$, EtONO $(15 \% \mathrm{v} / \mathrm{v}$ in ethanol), and Oxone were purchased from Aldrich. The ionization constants of compounds were determined by potentiometric titration with the GlpKa apparatus (Sirius Analytical Instruments Ltd., Forest Row, East Sussex, U.K.). At least three separate $20 \mathrm{~mL}$ aqueous solutions of the compounds (about $1 \mathrm{mM}$ ) were initially acidified to $\mathrm{pH} 1.8$ with $\mathrm{HCl}(0.5 \mathrm{~N})$. The solutions were then titrated with standardized $0.5 \mathrm{~N} \mathrm{KOH}$ to $\mathrm{pH} 12.2$. The titrations were performed under nitrogen at $25.0 \pm 0.1^{\circ} \mathrm{C}$. Optical rotations of the isolated enantiomers were measured on a Perkin-Elmer 241 polamimeter in themostated cuvettes. Circular dichroism (CD) spectra were recorded at $20^{\circ} \mathrm{C}$ on an OLIS instrument in $0.1 \mathrm{M}$ $\mathrm{HCl}$ in $1.0 \mathrm{~cm}$ cuvettes.

Liquid Chromatography. Semipreparative chiral HPLC of $\mathbf{1 0}$, 15, and $\mathbf{1 8}$ was performed on a Crownpak CR $(+)$ column $(150$ $\mathrm{mm} \times 10 \mathrm{~mm}, 5 \mu \mathrm{m})$ equipped with a Crownpak CR guard column $(10 \mathrm{~mm} \times 4.0 \mathrm{~mm}, 5 \mu \mathrm{m})$ (Daicel Chemical Industries, Ltd., Japan) connected to a Jasco 880 pump, a Rheodyne 7125 injector, a $5 \mathrm{~mL}$ loop, a TSP UV100 detector $(230 \mathrm{~nm})$, and a Hitachi D-2000 Chromato-Integrator (Merck). The flow rate was $0.7 \mathrm{~mL} / \mathrm{min}$ for $\mathbf{1 0}$ and $1.5 \mathrm{~mL} / \mathrm{min}$ for $\mathbf{1 5}$ and $\mathbf{1 8}$. The column was kept at $0{ }^{\circ} \mathrm{C}$ using an ice bath for compound $\mathbf{1 0}$, and elution was at room temperature for $\mathbf{1 5}$ and $\mathbf{1 8}$. The mobile phase was aqueous $\mathrm{AcOH}(15 \mathrm{mM})$.

Analytical chiral HPLC, used for the determination of enantiomeric excess (ee) of the enantiomers of 10, 15, and 18, was performed using a Crownpak $\mathrm{CR}(-)$ column $(150 \mathrm{~mm} \times 4.0$ $\mathrm{mm}, 5 \mu \mathrm{m}$ ) (Daicel Chemical Industries, Ltd., Japan). The column was eluted with aqueous $\mathrm{AcOH}(15 \mathrm{mM})$, and the flow-rate was $0.4 \mathrm{~mL} / \mathrm{min}$. The column was thermostated at $1{ }^{\circ} \mathrm{C}$ for $(+)$ - and (-)-10 and at $10{ }^{\circ} \mathrm{C}$ for $(+)$ - and (-)-15 and $(+)-$ and (-)-18 using a Hetofrig thermostat. A TSP HPLC system consisting of a P2000 pump, an AC 3000 autosampler, and an SM 5000 PDA detector was connected to the column.

Ethyl [4-(Benzyloxy)-1,2,5-oxadiazol-3-yl]acetate (4). A solution of $\mathbf{3}(59.4 \mathrm{~g}, 412.3 \mathrm{mmol})$ in ethanol saturated with gaseous $\mathrm{HCl}(180 \mathrm{~mL})$ was stirred at room temperature overnight. The mixture was concentrated under reduced pressure and the resulting crude material was purified by flash chromatography (eluent, $\left.\mathrm{CH}_{2} \mathrm{Cl}_{2} / \mathrm{EtOH}(96 \% \mathrm{v} / \mathrm{v}), 9: 1 \mathrm{v} / \mathrm{v}\right)$ to give the ethyl ester of 3 that was directly used in the next step without any further purification. $\mathrm{K}_{2} \mathrm{CO}_{3}(70 \mathrm{~g}, 507.0 \mathrm{mmol})$ and benzyl bromide
(30 mL, $251.95 \mathrm{mmol})$ were added to an acetone $(600 \mathrm{~mL})$ solution of the ester previously obtained. The resulting mixture was refluxed for $3 \mathrm{~h}$ and then filtered. The filtrate was concentrated under reduced pressure, obtaining an oil that was purified preliminarily by flash chromatography (eluent, petroleum ether $\left(40-60{ }^{\circ} \mathrm{C}\right) /$ EtOAc, $\left.95: 5 \mathrm{v} / \mathrm{v}\right)$ and then distilled $\left(\mathrm{bp} \cong 152^{\circ} \mathrm{C}\right.$ at $2.4 \times 10^{-2}$ mbar) to give 4 as colorless oil. Yield $75 \%$. ${ }^{1} \mathrm{H}$ NMR $\left(\mathrm{CDCl}_{3}\right) \delta 1.22\left(\mathrm{t}, J=7.1 \mathrm{~Hz}, 3 \mathrm{H},-\mathrm{OCH}_{2} \mathrm{CH}_{3}\right), 3.74(\mathrm{~s}, 2 \mathrm{H}$, $\left.-\mathrm{CH}_{2} \mathrm{COO}-\right), 4.17\left(\mathrm{q}, \mathrm{J}=7.1 \mathrm{~Hz}, 2 \mathrm{H},-\mathrm{OCH}_{2} \mathrm{CH}_{3}\right), 5.36(\mathrm{~s}$, $\left.2 \mathrm{H}, \mathrm{PhCH} \mathrm{H}_{2} \mathrm{O}-\right), 7.38-7.42$ (m, 5H, arom). ${ }^{13} \mathrm{CNMR}\left(\mathrm{CDCl}_{3}\right) \delta$ 14.0, 28.4, 61.8, 74.0, 128.4, 128. 7, 128.9, 134.6, 141.7, 164.2, 167.2. MS (CI) $m / z 263(\mathrm{M}+1)^{+}$. Anal. $\left(\mathrm{C}_{13} \mathrm{H}_{14} \mathrm{~N}_{2} \mathrm{O}_{4}\right) \mathrm{C}, \mathrm{H}, \mathrm{N}$.

[4-(Benzyloxy)-1,2,5-oxadiazol-3-yl]acetic Acid (4a). NaOH $(6 \mathrm{M}, 13 \mathrm{~mL})$ was added over $20 \mathrm{~min}$ to a solution of $4(17.0 \mathrm{~g}$, $64.82 \mathrm{mmol})$ in ethanol $(96 \%, 230 \mathrm{~mL})$. The resulting suspension was concentrated under reduced pressure, and the residue was dissolved in water $(120 \mathrm{~mL})$. The solution was acidified with $6 \mathrm{M} \mathrm{HCl}$ and then extracted with dichloromethane $(2 \times$ $150 \mathrm{~mL}$ ). The organic layers were collected, dried, and concentrated under reduced pressure to obtain pure $\mathbf{4 a}$ as a white solid (mp 101-102 ${ }^{\circ} \mathrm{C}$ from diisopropyl ether/hexane, 7:3 v/v). Yield $88 \% .{ }^{1} \mathrm{H} \mathrm{NMR}\left(\mathrm{CDCl}_{3}\right) \delta 3.81\left(\mathrm{~s}, 2 \mathrm{H},-\mathrm{CH}_{2} \mathrm{COOH}\right), 5.36(\mathrm{~s}$, $2 \mathrm{H}, \mathrm{PhCH}_{2} \mathrm{O}-$ ) , 7.36-7.43 (m, 5H, arom), 11.34 (broad signal, $1 \mathrm{H},-\mathrm{COOH}) .{ }^{13} \mathrm{C} \mathrm{NMR}\left(\mathrm{CDCl}_{3}\right) \delta 28.0,74.2,128.4,128.7$, 129.0, 134.4, 140.9, 164.1, 175.5. MS (CI) $m / z 235(\mathrm{M}+1)^{+}$, Anal. $\left(\mathrm{C}_{11} \mathrm{H}_{10} \mathrm{~N}_{2} \mathrm{O}_{4}\right) \mathrm{C}, \mathrm{H}, \mathrm{N}$.

4-(Benzyloxy)-1,2,5-oxadiazole-3-carboxylic Acid (5). $\mathrm{KMnO}_{4}$ $(12.28 \mathrm{~g}, 77.72 \mathrm{mmol}$ ) was added portionwise over $15 \mathrm{~min}$ to an ice cooled solution of $\mathbf{4 a}(9.1 \mathrm{~g}, 38.96 \mathrm{mmol})$ in acetone $(90 \mathrm{~mL})$. The reaction mixture was stirred at room temperature for $40 \mathrm{~min}$ and then poured into $2 \mathrm{M} \mathrm{HCl}(90 \mathrm{~mL})$. The resulting mixture was filtered, and the solid residue was extensively washed with dichloromethane. The aqueous layer was extracted with dichloromethane $(2 \times 80 \mathrm{~mL})$, and the organic layers were collected, dried, and concentrated under reduced pressure to give $\mathbf{5}$ as a white solid (mp $106-107^{\circ} \mathrm{C}$ from hexane/diisopropyl ether). Yield $71 \%$. ${ }^{1} \mathrm{H}$ NMR $\left(\mathrm{CDCl}_{3}\right) \delta 5.45\left(\mathrm{~s}, 2 \mathrm{H}, \mathrm{PhCH}_{2} \mathrm{O}-\right), 7.3-7.5$ (m, 5H, arom), 10.91 (broad signal, $1 \mathrm{H},-\mathrm{COOH}) .{ }^{13} \mathrm{C} \mathrm{NMR}\left(\mathrm{CDCl}_{3}\right) \delta 74.8,128.7$, 128.8, 129.1, 134.0, 139.1, 161.6, 163.9. MS (CI) $m / z 233(\mathrm{M}+1)^{+}$. Anal. $\left(\mathrm{C}_{10} \mathrm{H}_{8} \mathrm{~N}_{2} \mathrm{O}_{4}\right) \mathrm{C}, \mathrm{H}, \mathrm{N}$.

Methyl 4-(Benzyloxy)-1,2,5-oxadiazole-3-carboxylate (6). A solution of $5(7.10 \mathrm{~g}, 32.25 \mathrm{mmol})$ in methanol saturated with $\mathrm{HCl}(160 \mathrm{~mL})$ was stirred at room temperature over $20 \mathrm{~h}$ and then concentrated under reduced pressure. The residue was treated with a saturated solution of $\mathrm{NaHCO}_{3}(60 \mathrm{~mL})$, and the resulting mixture was extracted with diethyl ether $(4 \times 50 \mathrm{~mL})$. The organic layers were collected, dried, and concentrated under reduced pressure to give 6 as a white solid ( $\mathrm{mp} 45-46^{\circ} \mathrm{C}$ from hexane). Yield 73\%. ${ }^{1} \mathrm{H}$ NMR $\left(\mathrm{CDCl}_{3}\right) 3.91\left(\mathrm{~s}, 3 \mathrm{H},-\mathrm{COOCH}_{3}\right), 5.35(\mathrm{~s}$, $\left.2 \mathrm{H}, \mathrm{PhCH} \mathrm{H}_{2} \mathrm{O}-\right), 7.29-7.43\left(\mathrm{~m}, 5 \mathrm{H}\right.$, arom). ${ }^{13} \mathrm{C} \mathrm{NMR}\left(\mathrm{CDCl}_{3}\right) \delta$ 53.1, 74.4, 128.3, 128.6, 128.9, 134.0, 139.2, 157.4, 163.7. MS (CI) $m / z 235(\mathrm{M}+1)^{+}$. Anal. $\left(\mathrm{C}_{11} \mathrm{H}_{10} \mathrm{~N}_{2} \mathrm{O}_{4}\right) \mathrm{C}, \mathrm{H}, \mathrm{N}$.

[4-(Benzyloxy)-1,2,5-oxadiazol-3-yl]methanol (7). $\mathrm{NaBH}_{4}$ $(2.59 \mathrm{~g}, 68.32 \mathrm{mmol})$ was added portionwise over $15 \mathrm{~min}$ to a solution of $6(4.00 \mathrm{~g}, 17.08 \mathrm{mmol})$ in dry ethanol $(100 \mathrm{~mL})$, and the mixture was stirred under inert atmosphere at room temperature. After $1 \mathrm{~h}$, the reaction mixture was poured into iced water $(300 \mathrm{~mL})$. The resulting mixture was extracted with diethyl ether $(2 \times 100 \mathrm{~mL})$. The organic layers were collected, dried, and concentrated under reduced pressure. The residue was purified by flash chromatography (eluent, dichloromethane) to afford 7 as a colorless oil. Yield $73 \% .{ }^{1} \mathrm{H}$ NMR $\left(\mathrm{CDCl}_{3}\right) \delta 2.19$ (broad t, $J=$ $\left.6.5 \mathrm{~Hz}, 1 \mathrm{H},-\mathrm{CH}_{2} \mathrm{OH}\right), 4.77\left(\mathrm{~d}, J=6.4 \mathrm{~Hz}, 2 \mathrm{H},-\mathrm{CH}_{2} \mathrm{OH}\right), 5.37$ (s, $\left.2 \mathrm{H}, \mathrm{PhCH}_{2} \mathrm{O}-\right), 7.32-7.70$ (m, 5H, arom). ${ }^{13} \mathrm{C} \mathrm{NMR}\left(\mathrm{CDCl}_{3}\right)$ $\delta$ 53.7, 74.2, 128.7, 128.8, 129.1, 134.4, 146.4, 163.6. MS (CI) $m / z$ $207(\mathrm{M}+1)^{+}$. Anal. $\left(\mathrm{C}_{10} \mathrm{H}_{10} \mathrm{~N}_{2} \mathrm{O}_{3}\right) \mathrm{C}, \mathrm{H}, \mathrm{N}$.

3-(Benzyloxy)-4-(bromomethyl)-1,2,5-oxadiazole (8). NBS (1.03 g, $5.82 \mathrm{mmol}$ ) was added portionwise over $35 \mathrm{~min}$ under inert atmosphere to a cooled $\left(-10^{\circ} \mathrm{C}\right)$ solution of $7(1.00 \mathrm{~g}, 4.85 \mathrm{mmol})$ and triphenylphosphine $(1.52 \mathrm{~g}, 5.82 \mathrm{mmol})$ in dry dichloromethane 
$(20 \mathrm{~mL})$. The reaction mixture was directly loaded onto a flash chromatography column (eluent, dichloromethane) to give $\mathbf{8}$ as a white solid ( $\mathrm{mp} 37-38^{\circ} \mathrm{C}$ triturated from diisopropyl ether). Yield $88 \% .{ }^{1} \mathrm{H}$ NMR $\left(\mathrm{CDCl}_{3}\right) \delta 4.41\left(\mathrm{~s}, 2 \mathrm{H},-\mathrm{CH}_{2} \mathrm{Br}\right), 5.40(\mathrm{~s}, 2 \mathrm{H}$, $\left.\mathrm{PhCH}_{2} \mathrm{O}-\right), 7.40-7.49$ (m, 5H, arom). ${ }^{13} \mathrm{C} \mathrm{NMR}\left(\mathrm{CDCl}_{3}\right) \delta 15.1$, 74.3, 128.5, 128.7, 129.1, 134.4, 144.4, 163.3. MS (CI) $m / z$ 269/271 $(\mathrm{M}+1)^{+}$. Anal. $\left(\mathrm{C}_{10} \mathrm{H}_{9} \mathrm{BrN}_{2} \mathrm{O}_{2}\right) \mathrm{C}, \mathrm{H}, \mathrm{N}$.

Diethyl [(tert-Butoxycarbonyl)amino $][(4-($ benzyloxy $)-1,2,5-$ oxadiazol-3-yl)methyl]malonate (9). $\mathrm{NaH}(60 \% \mathrm{w} / \mathrm{w}, 535 \mathrm{mg}$, $13.38 \mathrm{mmol}$ ) was added portionwise to an ice cooled solution of diethyl [(tert-butoxycarbonyl)amino]malonate (3.68 g, 13.38 $\mathrm{mmol})$ in dry THF (45 mL) kept under inert atmosphere. The reaction mixture was stirred at room temperature for $1 \mathrm{~h}$, and then a solution of $8(3.00 \mathrm{~g}, 11.15 \mathrm{mmol})$ in dry THF $(13 \mathrm{~mL})$ was added over $15 \mathrm{~min}$. The resulting mixture was stirred at room temperature for $18 \mathrm{~h}$ and then poured into a saturated solution of $\mathrm{NH}_{4} \mathrm{Cl}(150 \mathrm{~mL})$. The resulting mixture was extracted with diethyl ether $(100+50 \mathrm{~mL})$. The organic layers were collected, dried, and concentrated under reduced pressure to afford a solid white material. The crude material was triturated with diisopropyl ether to afford pure 9 as a white solid (mp $111-112^{\circ} \mathrm{C}$ ). Yield 94\%. ${ }^{1} \mathrm{H} \mathrm{NMR}\left(\mathrm{CDCl}_{3}\right) \delta 1.20(\mathrm{t}, J=7.1 \mathrm{~Hz}, 6 \mathrm{H}$, $\left.-\mathrm{COOCH}_{2} \mathrm{CH}_{3}\right), 1.38\left(\mathrm{~s}, 9 \mathrm{H},-\mathrm{NHCOOCH}\left(\mathrm{CH}_{3}\right)_{3}\right), 3.76(\mathrm{~s}$, $2 \mathrm{H}$, furazanC $\left.\mathrm{H}_{2}-\right), 4.06-4.30\left(\mathrm{~m}, 4 \mathrm{H},-\mathrm{COOCH}_{2} \mathrm{CH}_{3}\right), 5.31$ (s, $\left.2 \mathrm{H}, \mathrm{PhCH}_{2} \mathrm{O}-\right), 5.88\left(\mathrm{~s}, 1 \mathrm{H},-\mathrm{NHCOOC}\left(\mathrm{CH}_{3}\right)_{3}\right), 7.36-7.41$ (m, 4H, arom). ${ }^{13} \mathrm{C} \mathrm{NMR}\left(\mathrm{CDCl}_{3}\right) \delta 13.8,26.3,28.1,63.3,65.2$, 74.0, 80.7, 128.4, 128.7, 129.1, 134.6, 142.9, 154.0, 164.6, 166.9. MS (CI) $m / z 464(\mathrm{M}+1)^{+}$. Anal. $\left(\mathrm{C}_{22} \mathrm{H}_{29} \mathrm{~N}_{3} \mathrm{O}_{8}\right) \mathrm{C}, \mathrm{H}, \mathrm{N}$.

Diethyl [(tert-Butoxycarbonyl)amino][(4-hydroxy-1,2,5-oxadiazol-3-yl)methyl]malonate (9a). $\mathrm{Pd} / \mathrm{C}(10 \% \mathrm{w} / \mathrm{w}, 750 \mathrm{mg})$ was added to a solution of $9(4.63 \mathrm{~g}, 9.99 \mathrm{mmol})$ in dry THF $(90 \mathrm{~mL})$. The resulting mixture was vigorously stirred at room temperature under hydrogen for $1 \mathrm{~h}$. The resulting mixture was filtered on Celite, and the filtrate was concentrated under reduced pressure. The crude material was triturated with diisopropyl ether to afford pure 9a as a white solid (mp $145-146^{\circ} \mathrm{C}$ from diisopropyl ether). Yield 59\% ${ }^{1} \mathrm{H}$ NMR (DMSO) $\delta 1.33$ $\left(\mathrm{t}, J=7.8 \mathrm{~Hz}, 6 \mathrm{H},-\mathrm{COOCH}_{2} \mathrm{CH}_{3}\right), 1.50($ broad $\mathrm{s}, 9 \mathrm{H}$, $\left.-\mathrm{NHCOOCH}\left(\mathrm{CH}_{3}\right)_{3}\right), 3.66\left(\mathrm{~s}, 2 \mathrm{H}\right.$, furazanCH $\left.\mathrm{H}_{2}-\right), 4.2-4.5$ $\left(\mathrm{m}, 4 \mathrm{H},-\mathrm{COOCH}_{2} \mathrm{CH}_{3}\right), 6.79\left(\mathrm{~s}, 1 \mathrm{H},-\mathrm{NHCOOC}\left(\mathrm{CH}_{3}\right)_{3}\right)$, $12.68(\mathrm{~s}, 1 \mathrm{H}$, furazanOH $) .{ }^{13} \mathrm{C} \mathrm{NMR}\left(\mathrm{CDCl}_{3}\right) \delta 13.9,26.74$, 28.0, 63.3, 66.5, 83.9, 142.8, 158.1, 163.6, 166.4. MS (CI) $m / z 374$ $(\mathrm{M}+1)^{+}$. Anal. $\left(\mathrm{C}_{15} \mathrm{H}_{23} \mathrm{~N}_{3} \mathrm{O}_{8}\right) \mathrm{C}, \mathrm{H}, \mathrm{N}$.

$(R S)$-2-Amino-3-(4-hydroxy-1,2,5-oxadiazol-3-yl)propionic Acid (10). A suspension of 9a $(2.00 \mathrm{~g}, 5.36 \mathrm{mmol})$ in hydrobromic acid $(48 \% \mathrm{w} / \mathrm{w}, 50 \mathrm{~mL})$ was refluxed for $24 \mathrm{~h}$ and then concentrated under reduced pressure. The crude material was triturated with dry EtOAc and dissolved in water $(26 \mathrm{~mL}, 5 \% \mathrm{w} / \mathrm{w})$. The solution was percolated on IRA400 (conditioned with $1 \mathrm{M} \mathrm{AcOH}$ ) using water as eluent until neutrality and then with $\mathrm{AcOH}$ (from 1 to $3 \mathrm{M}$ ). The ninhydrin positive fractions were collected and concentrated under reduced pressure. The resulting crude material was finally purified by trituration with water to afford pure $\mathbf{1 0}$ as a white solid (mp $205-206{ }^{\circ} \mathrm{C}$ dec from water). Yield 53\%. ${ }^{1} \mathrm{H}$ NMR $\left(\mathrm{D}_{2} \mathrm{O}\right) \delta 3.14-3.28\left(\mathrm{~m}, 2 \mathrm{H},-\mathrm{CH}_{2} \mathrm{CH}-\right)$, $4.10\left(\mathrm{dd}, J=5.7 \mathrm{~Hz}, J=6.8 \mathrm{~Hz}, 1 \mathrm{H},-\mathrm{CH}_{2} \mathrm{CH}-\right) .{ }^{13} \mathrm{C} \mathrm{NMR}$ $\left(\mathrm{D}_{2} \mathrm{O}\right) \delta 24.1,52.4,145.5,165.1,172.6$. MS (CI) $m / z 174(\mathrm{M}+1)^{+}$. Anal. $\left(\mathrm{C}_{5} \mathrm{H}_{7} \mathrm{~N}_{3} \mathrm{O}_{4} \cdot 0.1 \mathrm{H}_{2} \mathrm{O}\right) \mathrm{C}, \mathrm{H}, \mathrm{N}$.

(-)-2-Amino-3-(4-hydroxy-1,2,5-oxadiazol-3-yl)propionic Acid $[(-)-10]$ and (+)-2-Amino-3-(4-hydroxy-1,2,5-oxadiazol-3-yl)propionic Acid [(+)-10]. Compound 10 (250 mg, $1.43 \mathrm{mmol})$ was dissolved in aqueous $\mathrm{AcOH}(15 \mathrm{mM})(100 \mathrm{~mL})$, filtered through an MV filter $(0.45 \mu \mathrm{m}$, Waters), and resolved in $5 \mathrm{mg}$ injections. The collected fractions of the first eluting peak were pooled, evaporated, re-evaporated three times from water, and dried in vacuo to give (-) $-10\left(\mathrm{mp} 175-176^{\circ} \mathrm{C} \mathrm{dec}\right)$. Yield (119 mg, 95\%). ${ }^{1} \mathrm{H}$ NMR $\left(\mathrm{D}_{2} \mathrm{O}\right) \delta 3.30(\mathrm{dd}, J=6.9 \mathrm{~Hz}, J=5.4 \mathrm{~Hz}, 1 \mathrm{H}$, $-\mathrm{CH} H-), \delta 3.31(\mathrm{dd}, J=6.9 \mathrm{~Hz}, J=5.4 \mathrm{~Hz}, 1 \mathrm{H},-\mathrm{CH} H-), \delta$ $4.18(\mathrm{dd}, J=7.2 \mathrm{~Hz}, J=6.9 \mathrm{~Hz}, 1 \mathrm{H},-\mathrm{CH}-)$. ee $=99.6 \% .[\alpha]_{\mathrm{D}}^{25}$ $-16^{\circ}(c 0.42,0.1 \mathrm{M} \mathrm{HCl}) . \Delta \varepsilon(210 \mathrm{~nm})=-0.36 \mathrm{~m}^{2} / \mathrm{mol}$. Anal.
$\left(\mathrm{C}_{5} \mathrm{H}_{7} \mathrm{~N}_{3} \mathrm{O}_{4} \cdot 0.2 \mathrm{H}_{2} \mathrm{O}\right) \mathrm{C}, \mathrm{H}, \mathrm{N}$. The collected fractions of the second eluting peak were pooled, evaporated, re-evaporated three times from water, and dried in vacuo to give $(+)-\mathbf{1 0}(\mathrm{mp} \mathrm{176-}$ $\left.177{ }^{\circ} \mathrm{C} \mathrm{dec}\right)$. Yield $(117 \mathrm{mg}, 95 \%)$. ${ }^{1} \mathrm{H}$ NMR spectrum of $(+)-10$ was identical to that of $(-)-\mathbf{1 0}$. ee $=98.9 \%$. $[\alpha]_{\mathrm{D}}^{25}+18^{\circ}(c 0.43,0.1$ $\mathrm{M} \mathrm{HCl}) . \Delta \varepsilon(210 \mathrm{~nm})=+0.36 \mathrm{~m}^{2} / \mathrm{mol}$. Anal. $\left(\mathrm{C}_{5} \mathrm{H}_{7} \mathrm{~N}_{3} \mathrm{O}_{4}\right.$. $\left.0.2 \mathrm{H}_{2} \mathrm{O}\right) \mathrm{C}, \mathrm{H}$. N: calcd, 23.78; found, 23.19.

Ethyl 2-[4-(Benzyloxy)-1,2,5-oxadiazol-3-yl](hydroxyimino)acetate (11). A solution of $4(5.00 \mathrm{~g}, 19.03 \mathrm{mmol})$ in dry ethanol $(60 \mathrm{~mL})$ was added over $5 \mathrm{~min}$ to a cooled $\left(0^{\circ} \mathrm{C}\right)$ solution of $\mathrm{NaH}$ $(60 \% \mathrm{w} / \mathrm{w}, 913 \mathrm{mg}, 22.8 \mathrm{mmol})$ in dry ethanol $(75 \mathrm{~mL})$, kept under inert atmosphere. The mixture was stirred at $0{ }^{\circ} \mathrm{C}$ for $30 \mathrm{~min}$, and then an ethanolic solution of EtONO $(15 \% \mathrm{w} / \mathrm{w}$, $24 \mathrm{~mL}, 38.2 \mathrm{mmol}$ ) was added dropwise. The reaction mixture was allowed to reach room temperature and then stirred for $20 \mathrm{~h}$. After addition of glacial acetic acid $(1.3 \mathrm{~mL})$, the mixture was poured into water $(250 \mathrm{~mL})$. The resulting mixture was extracted with diethyl ether $(3 \times 100 \mathrm{~mL})$. The organic layers were collected, dried, and concentrated under reduced pressure. The resulting crude material was purified by flash chromatography (eluent, petroleum ether $\left.\left(40-60^{\circ} \mathrm{C}\right) / \mathrm{EtOAc}, 8: 2 \mathrm{v} / \mathrm{v}\right)$ to afford 11 as a white solid as a pure mixture of the two geometrical isomers in variable ratio. Yield $85 \% .{ }^{1} \mathrm{H}$ NMR (most abundant isomer, $\left.\mathrm{CDCl}_{3}\right) \delta 1.28\left(\mathrm{t}, J=7.1 \mathrm{~Hz}, 3 \mathrm{H},-\mathrm{OCH}_{2} \mathrm{CH}_{3}\right), 4.36(\mathrm{q}, J=7.2$ $\left.\mathrm{Hz}, 2 \mathrm{H},-\mathrm{OCH}_{2} \mathrm{CH}_{3}\right), 5.39$ (s, $2 \mathrm{H}, \mathrm{PhCH}_{2} \mathrm{O}-$ ), $7.37-7.41(\mathrm{~m}$, $5 \mathrm{H}$, arom $), 10.24(\mathrm{~s}, 1 \mathrm{H},=\mathrm{NOH}) .{ }^{1} \mathrm{H}$ NMR (less abundant isomer, $\left.\mathrm{CDCl}_{3}\right) \delta 1.36\left(\mathrm{t}, J=7.1 \mathrm{~Hz}, 3 \mathrm{H},-\mathrm{OCH}_{2} \mathrm{CH}_{3}\right), 4.44$ (q, $\left.J=7.1 \mathrm{~Hz}, 2 \mathrm{H},-\mathrm{OCH}_{2} \mathrm{CH}_{3}\right), 5.36\left(\mathrm{~s}, 2 \mathrm{H}, \mathrm{PhCH}_{2} \mathrm{O}-\right)$, 7.27-7.31 (m, 5H, arom), 10.90 (broad signal, $1 \mathrm{H},=\mathrm{NOH}$ ). MS (CI) $m / z 292(\mathrm{M}+1)^{+}$. Anal. $\left(\mathrm{C}_{13} \mathrm{H}_{13} \mathrm{~N}_{3} \mathrm{O}_{5}\right) \mathrm{C}, \mathrm{H}, \mathrm{N}$.

Ethyl $(R S)$-2-Amino-(4-hydroxy-1,2,5-oxadiazol-3-yl)acetate Hydrochloride (11a). Dry ethanol saturated with gaseous $\mathrm{HCl}$ $(15 \mathrm{~mL})$ and $\mathrm{Pd} / \mathrm{C}(10 \% \mathrm{w} / \mathrm{w}, 400 \mathrm{mg})$ were added to a solution of $11(1.00 \mathrm{~g}, 3.43 \mathrm{mmol})$ in dry ethanol $(35 \mathrm{~mL})$. The resulting mixture was kept in a sealed Paar reactor under $20 \mathrm{~atm}$ of hydrogen for $4 \mathrm{~h}$. The mixture was filtered on Celite and the filtrate was concentrated under reduced pressure, obtaining a solid crude material. The crude was triturated with diisopropyl ether to afford pure 11a as a white solid (mp $\left.162{ }^{\circ} \mathrm{C} \mathrm{dec}\right)$. Yield $90 \% .{ }^{1} \mathrm{H}$ NMR (DMSO) $\delta 1.19\left(\mathrm{t}, J=7.1 \mathrm{~Hz} 3 \mathrm{H},-\mathrm{OCH}_{2} \mathrm{CH}_{3}\right)$, $4.25\left(\mathrm{q}, J=7.1 \mathrm{~Hz} 2 \mathrm{H},-\mathrm{CH}_{2} \mathrm{CH}_{3}\right), 5.76(\mathrm{~s}, 1 \mathrm{H},-\mathrm{CHCOO})$, 10.34 (broad signal). ${ }^{13} \mathrm{C}$ NMR (DMSO) $\delta 13.6,45.1,62.9$, 142.4, 162.3, 164.9. MS (CI) $m / z 188(\mathrm{M}+1)^{+}$. Anal. $\left(\mathrm{C}_{6} \mathrm{H}_{9} \mathrm{~N}_{3} \mathrm{O}_{4} \cdot \mathrm{HCl} \cdot 0.1 \mathrm{H}_{2} \mathrm{O}\right) \mathrm{C}, \mathrm{H}, \mathrm{N}$.

( $R S$ )-2-Amino-(4-hydroxy-1,2,5-oxadiazol-3-yl)acetic Acid (12). A solution of 11a $(760 \mathrm{mg}, 2.01 \mathrm{mmol})$ in $6 \mathrm{M} \mathrm{HCl} \mathrm{(30}$ $\mathrm{mL}$ ) was stirred at $70{ }^{\circ} \mathrm{C}$ for $4 \mathrm{~h}$. The resulting mixture was concentrated under reduced pressure. The crude material was purificated by trituration with water to afford pure $\mathbf{1 2}$ as a white solid (mp $156-158{ }^{\circ} \mathrm{C}$ dec from water). Yield $86 \%{ }^{1} \mathrm{H}$ $\mathrm{NMR}\left(\mathrm{D}_{2} \mathrm{O}\right) \delta 5.11(\mathrm{~s}, 1 \mathrm{H},-\mathrm{CHCOOH}) .{ }^{13} \mathrm{C} \mathrm{NMR}\left(\mathrm{D}_{2} \mathrm{O} /\right.$ $\mathrm{NaOD}) \delta 50.5,151.8,168.6,177.7$. Anal. $\left(\mathrm{C}_{4} \mathrm{H}_{5} \mathrm{~N}_{3} \mathrm{O}_{4} \cdot \mathrm{H}_{2} \mathrm{O}\right)$ $\mathrm{C}, \mathrm{H}, \mathrm{N}$.

2-[4-(Benzyloxy)-1,2,5-oxadiazol-3-yl]ethanol (13). $\mathrm{LiAlH}_{4}$ $(2.60 \mathrm{~g}, 68.49 \mathrm{mmol})$ was added over $150 \mathrm{~min}$ to a cooled $\left(-50^{\circ} \mathrm{C}\right)$ solution of $4(11.0 \mathrm{~g}, 41.94 \mathrm{mmol})$ in dry THF $(65 \mathrm{~mL})$ kept under inert atmosphere. The reaction mixture was stirred at $-50{ }^{\circ} \mathrm{C}$ for $14 \mathrm{~h}$, then allowed to reach room temperature and poured into ice cooled $2 \mathrm{M} \mathrm{HCl}(160 \mathrm{~mL})$. The resulting mixture was extracted with diethyl ether $(2 \times 100 \mathrm{~mL})$. The organic layers were collected, dried, and concentrated under reduced pressure to afford a crude solid material which was purified by flash chromatography (eluent, petroleum ether $\left(40-60^{\circ} \mathrm{C}\right) /$ EtOAc, $8: 2 \mathrm{v} /$ $\mathrm{v})$, obtaining 13 as a white solid $\left(\mathrm{mp} 47-48^{\circ} \mathrm{C}\right.$ triturated from diisopropyl ether). Yield 53\%. ${ }^{1} \mathrm{H}$ NMR $\left(\mathrm{CDCl}_{3}\right) \delta 2.17(\mathrm{~s}, 1 \mathrm{H}$, $\left.-\mathrm{CH}_{2} \mathrm{CH}_{2} \mathrm{OH}\right), 2.90\left(\mathrm{t}, J=6.1 \mathrm{~Hz} 2 \mathrm{H},-\mathrm{CH}_{2} \mathrm{CH}_{2} \mathrm{OH}\right), 3.97(\mathrm{t}$, $\left.J=6.1 \mathrm{~Hz}, 2 \mathrm{H},-\mathrm{CH}_{2} \mathrm{CH}_{2} \mathrm{OH}\right), 5.32\left(\mathrm{~s}, 2 \mathrm{H}, \mathrm{PhCH}_{2} \mathrm{O}-\right)$, 7.35-7.46 (m, 5H, arom). ${ }^{13} \mathrm{C}$ NMR $\left(\mathrm{CDCl}_{3}\right) \delta 26.1,59.3$, 74.0, 128.5, 128.7, 129.0, 134.6, 145.3, 164.2. MS (CI) $m / z 221$ $(\mathrm{M}+1)^{+}$. Anal. $\left(\mathrm{C}_{11} \mathrm{H}_{12} \mathrm{~N}_{2} \mathrm{O}_{3} \cdot 0.1 \mathrm{H}_{2} \mathrm{O}\right) \mathrm{C}, \mathrm{H}, \mathrm{N}$. 
Diethyl $[($ tert-Butoxycarbonyl)amino] 2-(4-(benzyloxy)-1,2,5oxadiazol-3-yl)ethyl]malonate (14). Triflic anhydride $(1.95 \mathrm{~mL}$, $11.8 \mathrm{mmol}, 1.3$ equiv) was added over $1 \mathrm{~h}$ to a solution of $\mathbf{1 3}$ $(2,00 \mathrm{~g}, 9.08 \mathrm{mmol})$ and 2,6-lutidine $(1.27 \mathrm{~mL}, 10.90 \mathrm{mmol})$ in dry dichloromethane $(50 \mathrm{~mL})$, and the mixture was stirred under inert atmosphere at $-45^{\circ} \mathrm{C}$. The reaction mixture was allowed to reach room temperature and then stirred for $1 \mathrm{~h}$. The reaction mixture was directly loaded onto a flash chromatography column (eluent, dichloromethane) to give the moisture sensitive trifluoromethylsulfonyl derivative of $\mathbf{1 3}$ as a colorless oil in acceptable purity to be used immediately in the next step. $\mathrm{NaH}$ $(60 \% \mathrm{w} / \mathrm{w}, 400 \mathrm{mg}, 9.99 \mathrm{mmol})$ was added portionwise to an ice cooled solution of diethyl [(tert-butoxycarbonyl)amino]malonate $(2.75 \mathrm{~g}, 9.99 \mathrm{mmol})$ in dry THF $(40 \mathrm{~mL})$ kept under inert atmosphere. The mixture was stirred at room temperature for $1 \mathrm{~h}$, and then a solution in dry dichloromethane $(50 \mathrm{~mL})$ of the triflate, obtained in the previous step, was slowly added. The mixture was stirred for $15 \mathrm{~h}$ and then poured into a saturated solution of $\mathrm{NH}_{4} \mathrm{Cl}(100 \mathrm{~mL})$. The aqueous layer was extracted with dichloromethane $(100 \mathrm{~mL})$. The organic layers were collected, dried, and concentrated under reduced pressure. The crude material was purified by flash chromatography (eluent, petroleum ether $\left(40-60{ }^{\circ} \mathrm{C}\right) /$ EtOAc, $\left.9: 1 \mathrm{v} / \mathrm{v}\right)$ to afford 14 as a white solid ( $\mathrm{mp} 62^{\circ} \mathrm{C}$ from hexane/diisopropyl ether, 5:1 v/v). Yield $73 \%$. ${ }^{1} \mathrm{H}$ NMR $\left(\mathrm{CDCl}_{3}\right) \delta 1.21(\mathrm{t}, J=7.1 \mathrm{~Hz}, 6 \mathrm{H}$, $\left.-\left(\mathrm{COOCH}_{2} \mathrm{CH}_{3}\right)_{2}\right), 1.40\left(\mathrm{~s}, 9 \mathrm{H},-\mathrm{NHCOOCH}\left(\mathrm{CH}_{3}\right)_{3}\right), 2.58-$ 2.60/2.70-2.73 (m, 4H, furazanC $\mathrm{H}_{2} \mathrm{CH}_{2}-/ \mathrm{m}, 4 \mathrm{H}$, furazan$\left.\mathrm{CH}_{2} \mathrm{CH}_{2}-\right), 4.13-4.24\left(\mathrm{~m}, 4 \mathrm{H},-\mathrm{COOCH}_{2} \mathrm{CH}_{3}\right), 5.33(\mathrm{~s}, 2 \mathrm{H}$, $\mathrm{PhCH}_{2} \mathrm{O}-$ ), 5.96 (broad signal, $\left.1 \mathrm{H},-\mathrm{NHCOOC}\left(\mathrm{CH}_{3}\right)_{3}\right)$, 7.37-7.47 (m, 5H, arom). ${ }^{13} \mathrm{C}$ NMR $\left(\mathrm{CDCl}_{3}\right) \delta 13.9,17.2$, $28.1,29.9,62.7,65.9,73.9,80.5,128.5,128.7,128.9,134.7$, 146.3, 153.9, 164.0, 167.7. MS (CI) $m / z 478(\mathrm{M}+1)^{+}$. Anal. $\left(\mathrm{C}_{23} \mathrm{H}_{31} \mathrm{~N}_{3} \mathrm{O}_{8}\right) \mathrm{C}, \mathrm{H}, \mathrm{N}$.

Diethyl [(tert-Butoxycarbonyl)amino][2-(4-hydroxy-1,2,5-oxadiazol-3-yl)ethyl]malonate (14a). $\mathrm{Pd} / \mathrm{C}(10 \% \mathrm{w} / \mathrm{w}, 300 \mathrm{mg})$ was added to a solution of $\mathbf{1 4}(2.12 \mathrm{~g}, 4.44 \mathrm{mmol})$ in dry ethanol $(40 \mathrm{~mL})$. The resulting suspension was vigorously stirred at room temperature under hydrogen for $1 \mathrm{~h}$. The resulting mixture was filtered on Celite, and the filtrate was concentrated under reduced pressure. The crude material was purified by flash chromatography (eluent, petroleum ether $\left(40-60{ }^{\circ} \mathrm{C}\right) /$ EtOAc from 8:2 v/v to $1: 1 \mathrm{v} / \mathrm{v})$ to give $\mathbf{1 4}$ as a white solid $\left(\mathrm{mp} 125^{\circ} \mathrm{C}\right.$, from diisopropyl ether). Yield $63 \%,{ }^{1} \mathrm{H} \mathrm{NMR}\left(\mathrm{CDCl}_{3}\right) \delta 1.25(\mathrm{t}$, $\left.J=7.2 \mathrm{~Hz}, 6 \mathrm{H},-\mathrm{COOCH}_{2} \mathrm{CH}_{3}\right), 1.44$ (s, 9H, - NHCOOCH$\left.\left(\mathrm{CH}_{3}\right)_{3}\right), 2.69-2.77\left(\mathrm{~m}, 2 \mathrm{H}\right.$, furazanC $\left.\mathrm{H}_{2} \mathrm{CH}_{2}-\right), 4.15-4.34(\mathrm{~m}$, $\left.4 \mathrm{H},-\mathrm{COOCH}_{2} \mathrm{CH}_{3}\right), 6.04\left(\mathrm{~s}, 1 \mathrm{H},-\mathrm{N} H \mathrm{COOC}\left(\mathrm{CH}_{3}\right)_{3}\right), 10.3$ (broad signal, $1 \mathrm{H}$, furazanO $H) .{ }^{13} \mathrm{C} \mathrm{NMR}\left(\mathrm{CDCl}_{3}\right) \delta 13.9,17.1$, 28.1, 30.0, 62.9, 65.9, 80.9, 147.0, 154.2, 162.4, 167.7. MS (CI) $m / z 388(\mathrm{M}+1)^{+}$. Anal. $\left(\mathrm{C}_{16} \mathrm{H}_{25} \mathrm{~N}_{3} \mathrm{O}_{8}\right) \mathrm{C}, \mathrm{H}, \mathrm{N}$.

( $R S$ )-2-Amino-4-(4-hydroxy-1,2,5-oxadiazol-3-yl)butanoic Acid (15). A suspension of $\mathbf{1 4 a}(1.28,3.29 \mathrm{mmol})$ in hydrobromic acid $(48 \% \mathrm{w} / \mathrm{w}, 30 \mathrm{~mL})$ was refluxed for $24 \mathrm{~h}$ and then concentrated under reduced pressure. The resulting crude solid material was triturated with dry EtOAc and then dissolved in water $(26 \mathrm{~mL}, 5 \%$ $\mathrm{w} / \mathrm{w}$ ). The solution was percolated on IRA400 (conditioned with $1 \mathrm{M} \mathrm{AcOH}$ ) using water as eluent until neutrality and then aqueous $\mathrm{AcOH}$ (from 1 to $3 \mathrm{M}$ ). Ninhydrin positive fractions were collected and concentrated under pressure. The resulting crude material was triturated with water to afford $\mathbf{1 5}$ as a white solid ( $\mathrm{mp}$ $202{ }^{\circ} \mathrm{C}$ dec from water). Yield $70 \% .{ }^{1} \mathrm{H}$ NMR $\left(\mathrm{D}_{2} \mathrm{O}\right) \delta 1.98-2.30$ $\left(\mathrm{m}, 2 \mathrm{H},-\mathrm{CH}_{2} \mathrm{CH}-\right), 2.52-2.82\left(\mathrm{~m}, 2 \mathrm{H},-\mathrm{CH}_{2} \mathrm{CH}_{2}-\right), 3.78(\mathrm{t}$, $\left.J=6.3 \mathrm{~Hz}, 1 \mathrm{H},-\mathrm{CH}_{2} \mathrm{CH}-\right) .{ }^{13} \mathrm{C} N M R\left(\mathrm{D}_{2} \mathrm{O}\right) \delta 18.2,27.3,53.5$, 147.8, 163.5, 173.4. $\mathrm{MS}(\mathrm{CI}) m / z 188(\mathrm{M}+1)^{+}$. Anal. $\left(\mathrm{C}_{6} \mathrm{H}_{9} \mathrm{~N}_{3} \mathrm{O}_{4}\right)$ C, H, N.

(-)-2-Amino-4-(4-hydroxy-1,2,5-oxadiazol-3-yl)butanoic Acid [(-)-15] and (+)-2-Amino-4-(4-hydroxy-1,2,5-oxadiazol-3-yl)butanoic Acid [(+)-15]. A solution of $\mathbf{1 5}(250 \mathrm{mg}, 1.34 \mathrm{mmol})$ in aqueous AcOH $(15 \mathrm{mM})(100 \mathrm{~mL})$ was filtered through an MV filter $(0.45 \mu \mathrm{m}$, Waters $)$ and resolved in $15 \mathrm{mg}$ injections. The collected fractions of the first eluting peak were pooled, evaporated, re-evaporated three times from water, and dried in vacuo to give (-)-15 ( $\left.\mathrm{mp} 176-177^{\circ} \mathrm{C} \mathrm{dec}\right)$. Yield (122 mg, 98\%). ${ }^{1} \mathrm{H}$ NMR $\left(\mathrm{D}_{2} \mathrm{O}\right) \delta 2.25-2.34\left(\mathrm{~m}, 2 \mathrm{H},-\mathrm{CH}_{2} \mathrm{CH}-\right), 2.81-2.88$ (m, 2H, furazan- $\mathrm{CH}_{2} \mathrm{CH}_{2}-$ ), $3.86(\mathrm{t}, \mathrm{J}=6.3 \mathrm{~Hz}, 1 \mathrm{H},-\mathrm{CH}-$ ). ee $=99.9 \% .[\alpha]_{\mathrm{D}}^{25}-32^{\circ}(c 0.43,0.1 \mathrm{M} \mathrm{HCl}) . \Delta \varepsilon(210 \mathrm{~nm})=$ $-0.46 \mathrm{~m}^{2} / \mathrm{mol}$. Anal. $\left(\mathrm{C}_{6} \mathrm{H}_{9} \mathrm{~N}_{3} \mathrm{O}_{4} \cdot 0.85 \mathrm{H}_{2} \mathrm{O}\right) \mathrm{C}, \mathrm{H}, \mathrm{N}$. The collected fractions of the second eluting peak were pooled, evaporated, re-evaporated three times from water, and dried in vacuo to give (+)-15 (mp 175-176 $\left.{ }^{\circ} \mathrm{C} \mathrm{dec}\right)$. Yield (121 mg, 97\%). ${ }^{1} \mathrm{H}$ NMR spectrum of $(+)-\mathbf{1 5}$ was virtually identical with that of $(-)-\mathbf{1 5}$. ee $=99.5 \% \cdot[\alpha]_{\mathrm{D}}^{25}+35^{\circ}(c 0.46,0.1 \mathrm{M} \mathrm{HCl}) . \Delta \varepsilon(210 \mathrm{~nm})=$ $+0.42 \mathrm{~m}^{2} / \mathrm{mol}$. Anal. $\left(\mathrm{C}_{6} \mathrm{H}_{9} \mathrm{~N}_{3} \mathrm{O}_{4} \cdot 0.85 \mathrm{H}_{2} \mathrm{O}\right) \mathrm{C}, \mathrm{H}, \mathrm{N}$.

Diethyl [(tert-Butoxycarbonyl)amino] $\{3-[4-($ phenylsulfonyl)1,2,5-oxadiazol-3-yl)]propyl \}malonate (17). Triflic anhydride $(2.22 \mathrm{~mL}, 13.42 \mathrm{mmol})$ was added to a solution of $\mathbf{1 6}(3.00 \mathrm{~g}$, $11.18 \mathrm{mmol})$ and 2,6-lutidine $(1.56 \mathrm{~mL}, 13.42 \mathrm{mmol})$ in dry dichloromethane $(60 \mathrm{~mL})$ cooled $\left(-45^{\circ} \mathrm{C}\right)$ under inert atmosphere. The reaction mixture was allowed to reach room temperature and then stirred for $1 \mathrm{~h}$. The reaction mixture was then loaded onto a flash chromatography column (dichloromethane), obtaining the moisture sensitive trifluoromethansulfonate of $\mathbf{1 6}$ as colorless oil in acceptable purity to be used immediately in the next step. $\mathrm{NaH}(60 \% \mathrm{w} / \mathrm{w}, 492 \mathrm{mg})$ was added portionwise to a solution of diethyl [(tert-butoxycarbonyl)amino]malonate $(3.39 \mathrm{~g}, 12.30 \mathrm{mmol})$ in dry THF $(24 \mathrm{~mL})$, kept under inert atmosphere. The mixture was stirred at room temperature for $1 \mathrm{~h}$. Then a solution of triflate, obtained in the previous step, in dry dichloromethane $(60 \mathrm{~mL})$ was added over $1.5 \mathrm{~h}$. The reaction mixture was stirred at room temperature and then poured into a saturated solution of $\mathrm{NH}_{4} \mathrm{Cl}(100 \mathrm{~mL})$. The resulting mixture was extracted with dichloromethane $(100+20$ $\mathrm{mL}$ ), and the collected organic layers were dried and concentrated under reduced pressure. The residue was purified by flash chromatography (eluent, petroleum ether $\left(40-60{ }^{\circ} \mathrm{C}\right)$ /diisopropyl ether, $1: 1 \mathrm{v} / \mathrm{v}$ ) to give a crude that by trituration with $\mathrm{EtOH}$ $(96 \% \mathrm{w} / \mathrm{w})$ afforded pure 17 as a white solid $\left(\mathrm{mp} 78{ }^{\circ} \mathrm{C}\right.$ from hexane/diisopropyl ether, 5:1 v/v). Yield $43 \% .{ }^{1} \mathrm{H} \mathrm{NMR}\left(\mathrm{CDCl}_{3}\right)$ $\delta 1.26\left(\mathrm{t}, J=7.1 \mathrm{~Hz} 6 \mathrm{H},-\mathrm{CH}_{2} \mathrm{CH}_{3}\right), 1.44\left(\mathrm{~s}, 9 \mathrm{H},-\mathrm{C}\left(\mathrm{CH}_{3}\right)_{3}\right)$, 1.68-1.79 (m, 2H, furazanCH $\left.\mathrm{CH}_{2} \mathrm{CH}_{2}\right), 2.42-2.47(\mathrm{~m}, 2 \mathrm{H}$, furazanCH $\left.\mathrm{CH}_{2} \mathrm{CH}_{2}\right), 3.02\left(\mathrm{t}, \mathrm{J}=7.5 \mathrm{~Hz}, 2 \mathrm{H}\right.$, furazanCH $\mathrm{CH}_{2}-$ $\left.\mathrm{CH}_{2}\right), 4.17-4.34\left(\mathrm{~m}, 4 \mathrm{H},-\mathrm{CH}_{2} \mathrm{CH}_{3}\right), 5.98(\mathrm{~s}, 1 \mathrm{H},-\mathrm{NHCOOC}-$ $\left.\left(\mathrm{CH}_{3}\right)_{3}\right), 7.63-8.08(\mathrm{~m}, 5 \mathrm{H}$, arom $) .{ }^{13} \mathrm{C} \mathrm{NMR}\left(\mathrm{CDCl}_{3}\right) \delta 14.0$, 21.6, 23.3, 28.2, 32.1, 62.6, 66.2, 80.4, 128.8, 129.8, 135.4, 138.1, 152.5, 153.9, 156.6, 168.0. MS (CI) $m / z 526(\mathrm{M}+1)^{+}$. Anal. $\left(\mathrm{C}_{23} \mathrm{H}_{31} \mathrm{~N}_{3} \mathrm{O}_{9} \mathrm{~S}\right) \mathrm{C}, \mathrm{H}, \mathrm{N}$.

(RS)-2-Amino-5-(4-hydroxy-1,2,5-oxadiazol-3-yl)pentanoic Acid (18). $\mathrm{NaOH}(5 \mathrm{M}, 8 \mathrm{~mL})$ was added to a solution of $\mathbf{1 7}(1.046 \mathrm{~g}$, $1.99 \mathrm{mmol})$ in DMSO $(8 \mathrm{~mL})$. The reaction mixture was heated at $70{ }^{\circ} \mathrm{C}$ for $2 \mathrm{~h}$, diluted with water $(10 \mathrm{~mL})$, and neutralized with $6 \mathrm{M}$ $\mathrm{HCl}$ until pH 7.5 was obtained. Oxone $(2.43 \mathrm{~g}, 3.95 \mathrm{mmol})$ was added to the mixture, maintaining the $\mathrm{pH}$ near 1.7 by adding $2 \mathrm{M}$ $\mathrm{NaOH}$. The resulting mixture was filtered, and the filtrate was extracted with diethyl ether $(20 \mathrm{~mL} \times 13)$. The organic layers were collected, dried, and concentrated under reduced pressure. The crude material was dissolved in hydrobromic acid $(48 \% \mathrm{w} / \mathrm{w}, 15$ $\mathrm{mL}$ ), and the resulting solution was refluxed for $72 \mathrm{~h}$. The mixture was concentrated under reduced pressure, and the resulting residue was dissolved in water. After repeating this step three times, the resulting crude material was triturated with dry EtOAc. The obtained crude solid was dissolved in water $(7 \mathrm{~mL})$ and the resulting solution was percolated on IRA400 (conditioned with 1 $\mathrm{M} \mathrm{AcOH}$ ) using water as eluent until neutrality was obtained and then aqueous $\mathrm{AcOH}$ (from 1 to $3 \mathrm{M}$ ). Ninhydrin positive fractions were collected and concentrated under reduced pressure. Trituration with water of the resulting crude material afforded pure 18 as a white solid (mp 200-202 ${ }^{\circ} \mathrm{C} \mathrm{dec}$, from water). Yield $47 \% .{ }^{1} \mathrm{H}$ $\operatorname{NMR}\left(\mathrm{D}_{2} \mathrm{O}\right) \delta 1.63-1.90\left(\mathrm{~m}, 4 \mathrm{H},-\mathrm{CH}_{2} \mathrm{CH}_{2} \mathrm{CH}-\right), 2.65(\mathrm{t}, J=$ $6.0 \mathrm{~Hz}, 2 \mathrm{H}$, furazanC $\left.\mathrm{H}_{2}-\right), 3.71\left(\mathrm{t}, J=6.0 \mathrm{~Hz}, 1 \mathrm{H},-\mathrm{CH}_{2} \mathrm{CH}-\right)$. ${ }^{13} \mathrm{C}$ NMR $\left(\mathrm{D}_{2} \mathrm{O}\right) \delta 22.3,23.0,34.6,56.1,151.9,169.3,183.8, \mathrm{MS}$ (CI) $m / z 188(\mathrm{M}+1)^{+}$. Anal. $\left(\mathrm{C}_{7} \mathrm{H}_{11} \mathrm{~N}_{3} \mathrm{O}_{4}\right) \mathrm{C}, \mathrm{H}, \mathrm{N}$. 
(-)-2-Amino-5-(4-hydroxy-1,2,5-oxadiazol-3-yl)pentanoic Acid [(-)-18] and (+)-2-Amino-5-(4-hydroxy-1,2,5-oxadiazol-3-yl)pentanoic Acid [(+)-18]. Compound 18 (250 mg, $1.24 \mathrm{mmol})$ was dissolved in aqueous $\mathrm{AcOH}(15 \mathrm{mM})(100 \mathrm{~mL})$, filtered through an MV filter ( $0.45 \mu \mathrm{m}$, Waters $)$, and resolved in $9 \mathrm{mg}$ injections. The collected fractions of the first eluting peak were pooled, evaporated, re-evaporated three times from water, and dried in vacuo to give (-)-18 (mp 182-184 $\left.{ }^{\circ} \mathrm{C} \mathrm{dec}\right)$. Yield (117 mg, 94\%). ${ }^{1} \mathrm{H}$ NMR $\left(\mathrm{D}_{2} \mathrm{O}\right): \delta 1.75-2.00\left(\mathrm{~m}, 4 \mathrm{H},-\mathrm{CH}_{2} \mathrm{CH}_{2} \mathrm{CH}-\right), \delta 2.74(\mathrm{t}, J=$ $7.0 \mathrm{~Hz}, 2 \mathrm{H}$, furazanC $\left.\mathrm{H}_{2}-\right), \delta 3.80(\mathrm{t}, J=5.8 \mathrm{~Hz}, 1 \mathrm{H},-\mathrm{CH}-$. ee $=99.9 \% \cdot[\alpha]_{\mathrm{D}}^{25}-18^{\circ}(c 0.45,0.1 \mathrm{M} \mathrm{HCl}) . \Delta \varepsilon(210 \mathrm{~nm})=$ $-0.42 \mathrm{~m}^{2} / \mathrm{mol}$. Anal. $\left(\mathrm{C}_{7} \mathrm{H}_{11} \mathrm{~N}_{3} \mathrm{O}_{4}\right) \mathrm{C}, \mathrm{H}, \mathrm{N}$. The collected fractions of the second eluting peak were pooled, evaporated, reevaporated three times from water, and dried in vacuo to give (+)-18 (mp 179-181 $\left.{ }^{\circ} \mathrm{C} \mathrm{dec}\right)$. Yield (117 mg, 94\%). ${ }^{1} \mathrm{H}$ NMR spectrum of $(+)-\mathbf{1 8}$ was identical with that of $(-)-\mathbf{1 8}$. ee $=99.1 \%$. $[\alpha]_{\mathrm{D}}^{25}+19^{\circ}(c 0.42,0.1 \mathrm{M} \mathrm{HCl}) . \Delta \varepsilon(210 \mathrm{~nm})=+0.46 \mathrm{~m}^{2} / \mathrm{mol}$. Anal. $\left(\mathrm{C}_{7} \mathrm{H}_{11} \mathrm{~N}_{3} \mathrm{O}_{4}\right) \mathrm{C}, \mathrm{H}, \mathrm{N}$.

Native iGluR Binding Assays. AMPA, KA, and NMDA receptor binding assays were performed using rat brain synaptic membranes from male Sprague-Dawley rats, and tissue preparation was prepared as earlier described. ${ }^{26}$ Affinities for native AMPA, KA, and NMDA receptors were determined using $5 \mathrm{nM}$ $\left[{ }^{3} \mathrm{H}\right] \mathrm{AMPA}(45.5 \mathrm{Ci} / \mathrm{mmol}),{ }^{27} 5 \mathrm{nM}\left[{ }^{3} \mathrm{H}\right] \mathrm{KA}(58 \mathrm{Ci} / \mathrm{mmol}),{ }^{28}$ and $2 \mathrm{nM}\left[{ }^{3} \mathrm{H}\right] \mathrm{CGP} 39653\left(50 \mathrm{Ci} / \mathrm{mmol}, K_{\mathrm{d}}=6 \mathrm{nM}\right),{ }^{29}$ respectively, with minor modifications as previously described. ${ }^{17}$ Nonspecific binding was determined using $1 \mathrm{mM}(S)$-Glu. Data were analyzed using GraphPad Prism, version 4.0 (GraphPad Software Inc., San Diego, CA) and fit to the equation $Y=Y_{\max }-\left(Y_{\max }[\text { inhibitor }]^{n}\right) /$ $\left(\mathrm{IC}_{50}{ }^{n}+[\text { inhibitor }]^{n}\right)$, where $Y$ is the binding as a percentage of total specific binding and $n$ is the Hill coefficient.

Recombinant iGluR Binding Assays. Rat iGluR2 $(R)_{\circ}$, iGluR $5(Q)_{1 \mathrm{~b}}$, iGluR6 $(V, C, R)_{\mathrm{A}}$, and iGluR $7_{\mathrm{A}}$ were inserted into recombinant baculoviruses, receptors expressed by infection of $S f 9$ insect cells and infected $S f 9$ cell membranes utilized for radioligand binding assays. Cells were maintained in BaculoGold Max-XP serum-free medium (BD Biosciences-Pharmingen, San Diego, CA) according to standard protocols in "Guide to Baculovirus Expression Vector Systems and Insect Cell Culture Techniques" (Life Technologies, Paisley, U.K.) and "Baculovirus Expression Vector System: Procedures and Methods Manual", second edition (Pharmingen). Drug affinities were determined by radioligand binding competition assays. $S f 9$ insect cell membranes expressing iGluR2 $(R)_{\mathrm{o}}$ were incubated with $2-5 \mathrm{nM}(R S)-\left[{ }^{3} \mathrm{H}\right] \mathrm{AMPA}(43.5-55.5 \mathrm{Ci} / \mathrm{mmol}$; Perkin-Elmer, Boston, MA) in the presence of $1 \mathrm{nM}$ to $0.1 \mathrm{mM}$ drug for $1-2 \mathrm{~h}$ at $4{ }^{\circ} \mathrm{C}$ in assay buffer $(50 \mathrm{mM}$ Tris$\mathrm{HCl}, 100 \mathrm{mM} \mathrm{KSCN}, 2.5 \mathrm{mM} \mathrm{CaCl}$, pH 7.2 at $\left.4{ }^{\circ} \mathrm{C}\right)$. Samples were filtered through Whatman (Kent, U.K.) GF/B filters and washed twice with $4{ }^{\circ} \mathrm{C}$ assay buffer. $S f 9$ membranes expressing iGluR5 $(Q)_{1 \mathrm{~b}}$, iGluR6 $(V, C, R)_{\mathrm{A}}$, and iGluR7 $7_{\mathrm{A}}$ were incubated with $\left.{ }^{3} \mathrm{H}\right] \mathrm{SYM} 2081\left(\left[{ }^{3} \mathrm{H}\right](2 S, 4 R)-4-\right.$ methylglutamic acid) $(47.9$ $\mathrm{Ci} / \mathrm{mmol}$; ARC Inc., St. Louis, MO) and $1-1000 \mu \mathrm{M}$ drug in assay buffer $\left(50 \mathrm{mM}\right.$ Tris- $\mathrm{HCl}, \mathrm{pH} 7.1$ at $\left.4{ }^{\circ} \mathrm{C}\right)$ for $1-2 \mathrm{~h}$ at $4{ }^{\circ} \mathrm{C}$. Samples were filtered through GF/B filters (UniFilter-96, PerkinElmer, Waltham MA) on a PerkinElmer FilterMate manifold using two washes with $4{ }^{\circ} \mathrm{C}$ assay buffer. Nonspecific binding was determined in the presence of $1 \mathrm{mM}(S)$-Glu. Radioactivity was determined as DPM by liquid scintillation counting. Competition data were analyzed using Grafit, version 3.00 (Erithacus Software Ltd., Horley, U.K.) and fit to equations as previously described for the determination of $K_{\mathrm{i}}{ }^{30}$

Molecular Biology. The rat AMPA-R clone iGluR $2(Q)_{\mathrm{i}}$ in the vector $\mathrm{pGEMHE}{ }^{3 \mathrm{P}}$ was used for preparation of high-expression cRNA transcripts for functional expression in oocytes. The iGluR2 $(Q)_{\mathrm{i}}$ variant was selected for efficacy measurements, since the $Q$-isoform of GluR2 allows for functional homomeric channels while the flip isoforms have greatest sensitivity to the desensitization-blocking drug cyclothiazide. cDNAs were grown in XL1 Blue bacteria (Stratagene, La Jolla, CA) and prepared using column purification (Qiagen, Chatsworth, CA). cRNA was synthesized from these cDNAs using the mMessage mMachine T7 mRNA-capping transcription kit (Ambion Inc., Austin, TX) and purified using RNeasy spin columns (Qiagen). Restriction and other molecular biological enzymes were obtained from New England BioLabs (Beverly, MA).

Cloned iGluR TEVC Electrophysiology. Surgical procedures were conducted under the approval of the Danish Ministry of Justice Animal Experiments Inspectorate (2004/561-876). Mature female Xenopus laevis (Nasco, Fort Atkinson, WI) were anesthetized using $0.1 \%$ ethyl 3 -aminobenzoate methanesulfonate (tricaine), and ovaries were surgically removed. The ovarian tissue was dissected and treated with $2 \mathrm{mg} / \mathrm{mL}$ collagenase (type I; Worthington Biochemical Corp., Lakewood, NJ) in nominally $\mathrm{Ca}^{2+}$-free Barth's medium (in mM: $88 \mathrm{NaCl}, 1 \mathrm{KCl}$, $0.33 \mathrm{Ca}\left(\mathrm{NO}_{3}\right)_{2}, 0.41 \mathrm{CaCl}_{2}, 0.82 \mathrm{MgSO}_{4}, 2.4 \mathrm{NaHCO}_{3}, 10$ HEPES, $\mathrm{pH}$ 7.4) for $2 \mathrm{~h}$ at room temperature. Oocytes were kept overnight in Barth's medium containing $0.10 \mathrm{mg} / \mathrm{mL}$ gentamicin (Sigma) and 1\% penicillin-streptomycin (Life Technologies, Paisley, U.K.) at $16{ }^{\circ} \mathrm{C}$. On the following day, oocytes were injected with $25-50 \mathrm{~nL}$ of cRNA $(\sim 1 \mathrm{mg} / \mathrm{mL})$. Oocytes were typically used for recordings from 3 to 10 days postinjection and were voltage-clamped with the use of a twoelectrode voltage clamp (GeneClamp 500B, Axon Instruments, Union City, CA) with both microelectrodes filled with $3 \mathrm{M} \mathrm{KCl}$. Recordings were made while the oocytes were continuously superfused with nominally $\mathrm{Ca}^{2+}$-free frog Ringer's solution (in mM: $115 \mathrm{NaCl}, 2 \mathrm{KCl}, 1.8 \mathrm{BaCl}_{2}, 5$ HEPES, pH 7.0). Drugs were dissolved in $\mathrm{Ca}^{2+}$-free frog Ringer's solution and added by bath application. Recordings were made at room temperature. Efficacy measurements of $(+)-\mathbf{1 0}$ were made at $\operatorname{iGluR} 2(Q)_{\mathrm{i}}$ at holding potentials from -15 to $-20 \mathrm{mV}$ in the presence of $100 \mu \mathrm{M}$ cyclothiazide in order to block receptor desensitization (cyclothiazide $\mathrm{EC}_{50}$ : $\operatorname{iGluR} 2(Q)_{\mathrm{i}}=5.2 \mu \mathrm{M}$ ). As a control for current rundown, oocytes were stimulated with $1 \mathrm{mM}(S)$-Glu plus $100 \mu \mathrm{M}$ cyclothiazide immediately prior to application of $300 \mu \mathrm{M}(+)-10$ plus $100 \mu \mathrm{M}$ cyclothiazide, with a washout period of 5-10 min between applications. The maximum response of $(+)$-10 was then expressed as a fraction of the $(S)$-Glu stimulation. ( $S$-Glu is defined as having an efficacy of unity. Concentration-response curves for agonists were analyzed to determine the $\mathrm{EC}_{50}$ and Hill value $\left(n_{\mathrm{H}}\right)$, using the logistic

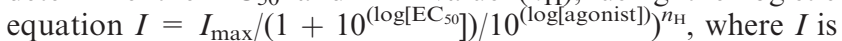
the measured current and $I_{\max }$ is the maximal steady-state current.

NMDA Receptor Pharmacology. Concentration-response data at the NMDA receptor subtype NR1/NR2A were generated essentially as previously described. ${ }^{23}$ Briefly, rat NR1 (GenBank accession no. U11418) and rat NR2A (D13211) were stably expressed in BHK-21 cells. These cells were then used for intracellular calcium measurements to detect changes in the concentration of intracellular calcium upon activation of the NMDA receptors. The measurements were performed using a fluometric imaging plate reader (FLIPR) (FLIPR384; Molecular Devices, Sunnyvale, CA) and the fluorescent calcium indicator Fluo-4 (Molecular Probes Invitrogen, Carlsbad, CA) as previously described. ${ }^{23}$ For the concentration-response data, each data point was averaged from four to six wells. These data points were fitted to the Hill equation: $F=F_{\min }+\left(\left(F_{\max }-\right.\right.$ $\left.\left.\left.F_{\min }\right) /\left(1+10^{(\log \mathrm{EC}} \mathrm{C}_{50}-\log [\mathrm{A}]\right) n_{\mathrm{H}}\right)\right) . F_{\max }$ is the maximal response to the agonist, $n_{\mathrm{H}}$ denotes the Hill coefficient, $[\mathrm{A}]$ is the agonist concentration, and $\mathrm{EC}_{50}$ is the agonist concentration that produces half-maximal response. The $\log \mathrm{EC}_{50}$ and $n_{\mathrm{H}}$ from the individual experiments were used to calculate the mean \pm standard error of mean (SEM). For graphical presentation, a representative data set \pm standard deviation (SD) from an individual experiment was selected. The maximal response evoked by $(S)$-Glu $\left(F_{\max ,(S) \text {-Glu }}\right)$ in the same experiment was normalized to 1 and the minimal response $\left(F_{\min }\right)$ was normalized to 0 . The normalized data points were then fitted to the Hill 
equation and plotted together with the resulting curve. Antagonist concentration - response data were calculated using a similar protocol, where instead of calculating the $\mathrm{EC}_{50}$ value, the concentration required to inhibit a response induced by $6 \mu \mathrm{M}$ $(S)$-Glu by $50 \%\left(\mathrm{IC}_{50}\right)$ was calculated.

Acknowledgment. This work was supported by MIUR (Grant COFIN 2003), the Lundbeck Foundation, and the Villum Kann Rasmussen Foundation

Supporting Information Available: Results from elemental analysis. This material is available free of charge via the Internet at http://pubs.acs.org.

\section{References}

(1) Dickenson, A. H. Amino Acids: Excitatory. In Neurotransmitters, Drugs and Brain Functions; Webster, R. A., Ed.; John Wiley: Chichester, U.K., 2002; pp 211-223.

(2) Bräuner-Osborne, H.; Egebjerg, J.; Nielsen, E. Ø.; Madsen, U.; Krogsgaard-Larsen, P. Ligands for glutamate receptors: design and therapeutic prospects. J. Med. Chem. 2000, 43, 2609-2645.

(3) Lima, L. M.; Barreiro, E. J. Bioisosterism: a useful strategy for molecular modification and drug design. Curr. Med. Chem. 2005, $12,23-49$.

(4) Thornber, C. W. Isosterism and molecular modification in drug design. Chem. Soc. Rev. 1979, 8, 563-580.

(5) Patani, G. A.; LaVoie, E. J. Bioisosterism: a rational approach in drug design. Chem. Rev. 1996, 96, 3147-3176.

(6) Kubinyi, H. Chemical similarity and biological activities. J. Braz. Chem. Soc. 2002, 13, 717-726.

(7) Kier, L. B.; Hall, L. H. Bioisosterism: quantitation of structure and property effects. Chem. Biodiversity 2004, 1, 138-151.

(8) Stefanic, P.; Dolenc, M. S. Aspartate and glutamate mimetic structures in biologically active compounds. Curr. Med. Chem. 2004, 11, 945-968.

(9) Johansen, T. N.; Greenwood, J. R.; Frydenvang, K.; Madsen, U.; Krogsgaard-Larsen, P. Stereostructure-activity studies on agonists at the AMPA and kainate subtypes of ionotropic glutamate receptors. Chirality 2003, 15, 167-179.

(10) Johansen, T. N.; Janin, Y. L.; Nielsen, B.; Frydenvang, K.; Brauner-Osborne, H.; Stensbøl, T. B.; Vogensen, S. B.; Madsen, U.; Krogsgaard-Larsen, P. 2-Amino-3-(3-hydroxy-1,2,5-thiadiazol-4-yl)propionic acid: resolution, absolute stereochemistry and enantiopharmacology at glutamate receptors. Bioorg. Med. Chem. 2002, 10, 2259-2266.

(11) Lolli, M. L.; Hansen, S. L.; Rolando, B.; Nielsen, B.; Wellendorph, P.; Madsen, K.; Larsen, O. M.; Kristiansen, U.; Fruttero, R.; Gasco, A.; Johansen, T. N. Hydroxy-1,2,5-oxadiazolyl moiety as bioisoster of the carboxy function. Synthesis, ionization constants, and pharmacological characterization of gamma-aminobutyric acid (GABA) related compounds. J. Med. Chem. 2006, 49, 44424446.

(12) Albert, A.; Serjeant, E. P. The Determination of Ionization Constants: A Laboratory Manual, 3rd ed.; Chapman and Hall: London, 1984

(13) Stensbøl, T. B.; Uhlmann, P.; Morel, S.; Eriksen, B. L.; Felding, J.; Kromann, H.; Hermit, M. B.; Greenwood, J. R.; BräunerOsborne, H.; Madsen, U.; Junager, F.; Krogsgaard-Larsen, P.; Begtrup, M.; Vedsø, P. Novel 1-hydroxyazole bioisosteres of glutamic acid. Synthesis, protolytic properties, and pharmacology. J. Med. Chem. 2002, 45, 19-31.

(14) Zimmermann, D.; Janin, Y. L.; Brehm, L.; Bräuner-Osborne, H.; Ebert, B.; Johansen, T. N.; Madsen, U.; Krogsgaard-Larsen, P. 3-Pyrazolone analogues of the 3-isoxazolol metabotropic excitatory amino acid receptor agonist homo-AMPA. Synthesis and pharmacological testing. Eur. J. Med. Chem. 1999, 34, 967-976.

(15) Clausen, R. P.; Bräuner-Osborne, H.; Greenwood, J. R.; Hermit, M. B.; Stensbøl, T. B.; Nielsen, B.; Krogsgaard-Larsen, P. Selective agonists at group II metabotropic glutamate receptors: synthesis, stereochemistry, and molecular pharmacology of $(S)$ - and $(R)-2-$ amino-4-(4-hydroxy[1,2,5]thiadiazol-3-yl)butyric acid. J. Med. Chem. 2002, 45, 4240-4245.

(16) Shinbo, T.; Yamagushi, T.; Nishimura, K.; Sugiura, M. Chromatographic separation of racemic amino acids by use of chiral crown ether-coated reversed-phase packings. J. Chromatogr. 1987, 405, $145-153$.

(17) Clausen, R. P.; Hansen, K. B.; Cali, P.; Nielsen, B.; Greenwood, J. R.; Begtrup, M.; Egebjerg, J.; Bräuner-Osborne, H. The respective $N$-hydroxypyrazole analogues of the classical glutamate receptor ligands ibotenic acid and $(R S)$-2-amino-2-(3-hydroxy5-methyl-4-isoxazolyl)acetic acid. Eur. J. Pharmacol. 2004, 499, $35-44$.

(18) Vogensen, S. B.; Frydenvang, K.; Greenwood, J. R.; Postorino, G.; Nielsen, B.; Pickering, D. S.; Ebert, B.; Bolcho, U.; Egebjerg, J.; Gajhede, M.; Kastrup, J. S.; Johansen, T. N.; Clausen, R. P.; Krogsgaard-Larsen, P. A tetrazolyl-substituted subtype-selective AMPA receptor agonist. J. Med. Chem. 2007, 50, 2408-2414.

(19) Bunch, L.; Johansen, T. H.; Bräuner-Osborne, H.; Stensbøl, T. B.; Johansen, T. N.; Krogsgaard-Larsen, P.; Madsen, U. Synthesis and receptor binding affinity of new selective GluR5 ligands. Bioorg. Med. Chem. 2001, 9, 875-879.

(20) Madsen, U.; Frydenvang, K.; Ebert, B.; Johansen, T. N.; Brehm, L.; Krogsgaard-Larsen, P. NMDA receptor agonists. Resolution, absolute stereochemistry and pharmacology of the enantiomers of 2-amino-2-(3-hydroxy-5-methyl-4-isoxazolyl)acetic acid (AMAA). J. Med. Chem. 1996, 39, 183-190.

(21) Sløk, F. A.; Ebert, B.; Lang, Y.; Krogsgaard-Larsen, P.; Lenz, S. M.; Madsen, U. Excitatory amino-acid receptor agonists. Synthesis and pharmacology of analogues of 2-amino-3-(3-hydroxy5-methylisoxazol-4-yl)propionic acid. Eur. J. Med. Chem. 1997, $32,329-338$

(22) Vogensen, S. B.; Clausen, R. P.; Greenwood, J. R.; Johansen, T. N.; Pickering, D. S.; Nielsen, B.; Ebert, B.; Krogsgaard-Larsen, P. Convergent synthesis and pharmacology of substituted tetrazolyl-2-amino-3-(3-hydroxy-5-methyl-4-isoxazolyl)propionic acid analogues. J. Med. Chem. 2005, 48, 3438-3442.

(23) Hansen, K. B.; Brauner-Osborne, H.; Egebjerg, J. Pharmacological characterization of ligands at recombinant NMDA receptor subtypes by electrophysiological recordings and intracellular calcium measurements. Comb. Chem. High Throughput Screening 2008, 11, 304-315.

(24) Katritzky, A. R.; Wallis, B.; Brownlee, R. T.; Topsom, R. D. The tautomerism of heteroaromatic compounds with 5-membered rings - VIII. Hydroxy-oxadiazoles or oxadiazolones. Tetrahedron 1965, 21, 1681-1692.

(25) Kawai, M.; Nyfeler, R.; Berman, J. M.; Goodman, M. Peptide Sweeteners. 5. Side-chain homologs relating zwitterionic and trifluoroacetylated amino-acid anilide and dipeptide sweeteners. J. Med. Chem. 1982, 25, 397-402.

(26) Ransom, R. W.; Stec, N. L. Cooperative modulation of $\left[{ }^{3} \mathrm{H}\right] \mathrm{MK}-$ 801 binding to the $N$-methyl-D-aspartate receptor ion channel complex by L-glutamate, glycine and polyamines. J. Neurochem. 1988, 51, 830-836.

(27) Honoré, T.; Nielsen, M. Complex structure of quisqualatesensitive glutamate receptors in rat cortex. Neurosci. Lett. 1985, $54,27-32$.

(28) Braitman, D. J.; Coyle, J. T. Inhibition of $\left[{ }^{3} \mathrm{H}\right] \mathrm{kainic}$ acid receptor binding by divalent cations correlates with ion affinity for the calcium channel. Neuropharmacology 1987, 26, 1247-1251.

(29) Sills, M. A.; Fagg, G.; Pozza, M.; Angst, C.; Brundish, D. E.; Hurt, S. D.; Wilusz, E. J.; Williams, M. $\left[{ }^{3}\right.$ H]CGP 39653: a new $N$-methylD-aspartate antagonist radioligand with low nanomolar affinity in rat brain. Eur. J. Pharmacol. 1991, 192, 19-24.

(30) Nielsen, B. S.; Banke, T. G.; Schousboe, A.; Pickering, D. S. Pharmacological properties of homomeric and heteromeric GluR1o and GluR3o receptors. Eur. J. Pharmacol. 1998, 360, 227-238.

(31) Liman, E. R.; Tytgat, J.; Hess, P. Subunit stoichiometry of a mammalian $\mathrm{K}^{+}$channel determined by construction of multimeric cDNAs. Neuron 1992, 9, 861-871. 